\title{
Negative dietary cation-anion difference and amount of calcium in prepartum diets: Effects on milk production, blood calcium, and health
}

\author{
K. M. Glosson, ${ }^{1,2 *}$ () X. Zhang, ${ }^{3 *}$ S. S. Bascom, ${ }^{4} \oplus$ A. D. Rowson, ${ }^{4}$ Z. Wang, ${ }^{3}$ and J. K. Drackley ${ }^{1} \dagger{ }^{\oplus}$ \\ ${ }^{1}$ Department of Animal Sciences, University of Illinois, Urbana 61801 \\ ${ }^{2}$ Phibro Animal Health Corp., 229 Radio Rd, Quincy, IL 62305 \\ ${ }^{3}$ Institute of Animal Nutrition, Key Laboratory of Low Carbon Culture and Safety Production in Cattle in Sichuan, Sichuan Agricultural University, \\ Chengdu, P. R. China 611130 \\ ${ }^{4}$ Phibro Animal Health Corp., Teaneck, NJ 07666-6712
}

\section{ABSTRACT}

Acidogenic prepartum diets with negative dietary cation-anion difference (DCAD) induce compensated metabolic acidosis, which stimulates calcium (Ca) mobilization before calving and decreases clinical and subclinical hypocalcemia postpartum. This strategy is often combined with limiting dietary Ca concentrations, which historically has been used to mobilize Ca prepartum to prepare cows for lactation. Supplemental dietary $\mathrm{Ca}$ in combination with a negative DCAD formulation that does not reverse the effect of compensated metabolic acidosis may be beneficial. Our objective was to determine the effects of prepartum dietary strategies on dry matter intake (DMI), milk production, peripartal Ca status, and health during the transition period in multiparous Holstein cows $(\mathrm{n}=81)$. Treatments during the last $28 \mathrm{~d}$ before calving were: (1) positive DCAD diet, $+6 \mathrm{mEq} / 100 \mathrm{~g}$ of $\mathrm{DM}$, target urine $\mathrm{pH}>7.5$, low dietary $\mathrm{Ca}(0.40 \% \mathrm{DM}$; CON $)$; (2) negative DCAD diet, $-24 \mathrm{mEq} / 100 \mathrm{~g}$ of $\mathrm{DM}$, target urine $\mathrm{pH} 5.5$ to 6.0 , low dietary $\mathrm{Ca}(0.40 \% \mathrm{DM}$; ND); or (3) negative DCAD diet, $-24 \mathrm{mEq} / 100 \mathrm{~g}$ of DM, target urine $\mathrm{pH} 5.5$ to 6.0 , , high dietary $\mathrm{Ca}(2.0 \%$ DM; NDCA). Preplanned treatment contrasts were: (1) CON versus (ND and NDCA), and (2) ND versus NDCA. Individual DMI were recorded daily. Cows were milked 3 times daily, with individual DMI and milk yield summarized by week. Whole blood sampled at calving and $24 \mathrm{~h}, 48 \mathrm{~h}$, and $4 \mathrm{~d}$ after calving was analyzed for ionized Ca concentration, and serum was analyzed for total Ca. Prepartum urine $\mathrm{pH}$ for cows fed ND or NDCA averaged 5.7, whereas cows fed CON remained $>7.5$. During the 3 wk before calving, cows

Received December 16, 2019.

Accepted March 12, 2020.

*These authors contributed equally to this work.

†Corresponding author: drackley@illinois.edu fed CON had greater DMI than cows fed ND or NDCA, with NDCA greater than ND. Postpartum DMI (\% of body weight) tended to be less for cows fed CON than for those fed ND or NDCA prepartum. Thresholds for subclinical hypocalcemia were ionized $\mathrm{Ca}<1.0 \mathrm{mM}$ at $24 \mathrm{~h}$, and total $\mathrm{Ca} \leq 2.125 \mathrm{~m} M$ at $48 \mathrm{~h}$ after calving. On average, blood Ca for cows fed CON indicated subclinical hypocalcemia, whereas blood Ca for cows fed ND or NDCA was greater than subclinical hypocalcemia thresholds for both ionized $\mathrm{Ca}$ and total Ca. No milk production differences were detected. Cows fed CON had an elevated adverse health score (calculated by assigning numerical values to recorded health events) and tended to have an elevated somatic cell count during the fresh period compared with cows fed ND or NDCA. Overall, an acidogenic diet prepartum without or with high $\mathrm{Ca}$ improved postpartum Ca status and health. Supplementation of additional $\mathrm{Ca}$ to the acidogenic diet had little effect.

Key words: calcium, production, transition, negative dietary cation-anion difference

\section{INTRODUCTION}

The transition period is arguably the most challenging time of cows' production cycle, with clinical and subclinical hypocalcemia (SCH) contributing a major portion of the challenges. Circulating Ca (calcium) concentration normally is kept within a narrow range, tightly regulated by parathyroid hormone (PTH), calcitriol, and calcitonin to maintain a plasma Ca concentration of 2.25 to $2.5 \mathrm{mM}$ (Goff and Horst, 1997). At the end of gestation, dairy cows require only enough Ca for maintenance, late-stage fetal growth, expected endogenous loss, and colostrogenesis, totaling approximately 20 to $32 \mathrm{~g} / \mathrm{d}$. However, at the onset of lactation, 30 to $50 \mathrm{~g} / \mathrm{d}$ of $\mathrm{Ca}$ is needed for milk production in high-producing dairy cows (Horst et al., 2005). Any delay in endocrine signaling or response to replenish the available circulating $\mathrm{Ca}$ pool can have detrimental 
effects on postpartum production and health (Overton and Waldron, 2004).

Clinical hypocalcemia, or milk fever, is defined as a serum total $\mathrm{Ca}(\mathbf{t C a})$ concentration $\leq 1.374 \mathrm{~m} M$ with physical signs of parturient paresis (Mulligan et al., 2006). Subclinical hypocalcemia has been described in the past as tCa concentrations of $\leq 2.0 \mathrm{mM}$ or $\leq 2.148$ $\mathrm{m} M$. The threshold for determining $\mathrm{SCH}$ depends on the correlation of tCa concentration with postpartum metabolic disorders or diseases being assessed (RamosNieves et al., 2009; Martinez et al., 2012). These disorders and diseases include ketosis, mastitis, metritis, displaced abomasum, and retained placenta (Mulligan and Doherty, 2008; Chapinal et al., 2012; Chamberlin et al., 2013). To consider the broadest definition of $\mathrm{SCH}$, the threshold of $\leq 2.125 \mathrm{~m} M$ of serum tCa at 48 $\mathrm{h}$ after calving has been adopted (Leno et al., 2017).

Calcium movement in the body includes intestinal absorption, bone resorption and calcification, and renal excretion and reabsorption. The constant exchange of $\mathrm{Ca}$ in the circulating $\mathrm{Ca}$ pool is referred to as $\mathrm{Ca}$ flux. The historically successful technique of limiting prepartum dietary $\mathrm{Ca}$ in a positive DCAD diet to prevent hypocalcemia, relies on limiting dietary $\mathrm{Ca}$ to below requirements to stimulate Ca mobilization from labile bone stores. However, maintenance for an individual animal can be as low as $25 \mathrm{~g} / \mathrm{d}$ (Crenshaw et al., 2011). This dietary strategy has fallen out of favor due to high cation-containing forages and an insensitivity to PTH signaling found in kidney PTH receptors when a positive DCAD diet is fed (Liesegang et al., 2007; Goff and Koszewski, 2018).

Alternatively, supplementing anionic salts to create an acidogenic prepartum diet has been used to prepare the Ca homeostatic system before calving (Goff et al., 2014). The negative DCAD formulation strategy causes compensated metabolic acidosis in prepartum cows, which decreases urine $\mathrm{pH}$ and increases urinary Ca excretion (Leno et al., 2017). Compensated metabolic acidosis also directly affects Ca availability by increasing bone resorption and tissue responsiveness to hormonal signals (Liesegang et al., 2007; Rodriguez et al., 2016). Under conditions of prepartum compensated metabolic acidosis, $\mathrm{Ca}$ is absorbed actively and passively from the rumen and small intestine and mobilized from bone stores to be excreted through the urine to maintain homeostasis. This continuous Ca flux creates a supply of available $\mathrm{Ca}$ to be used for the initiation of lactation when urinary $\mathrm{Ca}$ excretion is conserved (Grünberg et al., 2011; Megahed et al., 2018).

Another possible dietary option is to add dietary $\mathrm{Ca}$ to a partially acidogenic diet, targeting urine $\mathrm{pH}$ of 7.0, to increase Ca availability. However, increasing dietary
Ca has been shown to mitigate compensated metabolic acidosis through an increase in urine $\mathrm{pH}$ (Goff and Koszewski, 2018) and therefore reversing or limiting the benefits of compensated metabolic acidosis.

Our hypothesis was that increasing mobilization of $\mathrm{Ca}$ into the circulating $\mathrm{Ca}$ pool by feeding an acidogenic prepartum diet, targeting a urine $\mathrm{pH}$ of 5.5 to 6.0, would then allow for supplementation of dietary $\mathrm{Ca}$ to increase prepartum Ca flux (Lean et al., 2006). The objectives of our study were to evaluate the effects of 2 different prepartum dietary strategies: (1) a positive DCAD, low Ca diet compared with negative DCAD, acidogenic diets; and (2) low or high dietary Ca within a negative DCAD dietary strategy. Response variables included postpartum milk production, Ca status, and health.

\section{MATERIALS AND METHODS}

Multiparous Holstein cows $(\mathrm{n}=81)$ were provided by the University of Illinois Lincoln Avenue Dairy Facility (Urbana, IL). All procedures involving animals were conducted in accordance with the University of Illinois Institutional Animal Care and Use Committee (IACUC protocol 16115). The study was conducted from September 2016 to December 2017. Calving began in November 2016 and ended in September 2017, with no more than 2 wk between calvings throughout the experiment. Ryan et al. (2019) reported the design and partial methodology for the study, as well as reproductive performance of the cows.

Treatments were diets fed during the last $28 \mathrm{~d}$ before expected parturition: (1) a positive DCAD prepartum diet, targeting urine $\mathrm{pH}>7.5$, with low dietary $\mathrm{Ca}$ (0.40\% DM; CON); (2) a negative DCAD prepartum diet, targeting urine $\mathrm{pH} 5.5$ to 6.0, with low dietary $\mathrm{Ca}(0.40 \% \mathrm{DM}$; ND); or (3) a negative DCAD prepartum diet, targeting urine $\mathrm{pH} 5.5$ to 6.0 , with high dietary $\mathrm{Ca}(2.0 \% \mathrm{DM}$; NDCA). The 3 treatments were provided as TMR (Table 1). The nutrient analysis for each diet is shown in Table 2. The base portion of the diet, including wheat straw, corn silage, corn gluten feed, and soybean hulls, was kept constant among diets throughout the trial and was mixed in a TMR mixer with horizontal paddles fitted with knives (Keenan Systems, Borris, Ireland). Each diet had its own formulated grain mixture, which was added separately to the base mix in a Data Ranger (American Calan, Northwood, $\mathrm{NH}$ ) mixer. The treatment concentrates were reformulated as needed to correct DCAD formulation based on measured urine $\mathrm{pH}$ of the treatment group, but the same nutrient concentrations were maintained across all treatment diets. Treatment diets were always mixed 
and fed in the order of CON, ND, and then NDCA, to prevent contamination of Animate (Phibro Animal Health Corp., Teaneck, NJ) and Ca across diets. Between diets, 20 to $40 \mathrm{~kg}$ of the base mix was then mixed in the Data Ranger and discarded to provide a "cleaning" cycle. Water was added to the diets to maintain the DM at approximately $45 \%$ for the dry cow diets and about $50 \%$ for the lactation diet.
Cows were enrolled during the far-off dry period at 50 $\mathrm{d}$ before their expected calving date and remained on trial until $73 \mathrm{~d}$ postpartum. Cows were not enrolled if diagnosed with twins. Exclusion of first-calving heifers and cows carrying twins was based on the differences in nutritional requirements needed for still-growing heifers and cows carrying multiple calves. Treatments began $28 \mathrm{~d}$ before the expected calving date, and cows were

Table 1. Ingredient composition (\% of DM) of the close-up and lactation diets fed as TMR

\begin{tabular}{|c|c|c|c|c|}
\hline \multirow[b]{2}{*}{ Ingredient } & \multicolumn{3}{|c|}{ Treatment $^{1}$} & \multirow[b]{2}{*}{ Lactation } \\
\hline & $\mathrm{CON}$ & ND & NDCA & \\
\hline Corn silage & 32.10 & 32.10 & 32.10 & 36.61 \\
\hline Wheat straw & 36.31 & 36.31 & 36.31 & 2.34 \\
\hline Alfalfa hay & - & - & - & 11.26 \\
\hline Corn gluten feed & 8.25 & 8.25 & 8.25 & 8.34 \\
\hline Corn grain, ground & - & - & - & 18.81 \\
\hline Soybean hulls, pelleted & 6.60 & 6.60 & 6.60 & 4.32 \\
\hline Soybean meal & 5.78 & 5.78 & 5.78 & - \\
\hline ProVAAl AAdvantage ${ }^{2}$ & 2.48 & 2.48 & 2.48 & 1.87 \\
\hline Canola meal, expeller & - & - & - & 11.79 \\
\hline Rumen-protected lysine $^{3}$ & - & - & - & 0.63 \\
\hline Rumen-protected methionine ${ }^{4}$ & - & - & - & 0.15 \\
\hline Animate $^{5}$ & - & 4.13 & 4.13 & - \\
\hline Calcium carbonate & - & - & 2.87 & - \\
\hline Wheat middlings & 6.20 & 3.38 & 0.83 & - \\
\hline Clay $^{6}$ & 1.24 & 0.41 & - & - \\
\hline Salt, white & 0.08 & - & - & - \\
\hline Sodium monophosphate & - & 0.08 & 0.16 & - \\
\hline Magnesium sulfate $\cdot 7 \mathrm{H}_{2} \mathrm{O}$ & 0.58 & - & - & - \\
\hline Magnesium oxide & 0.33 & - & - & - \\
\hline UI mineral premix prepartum ${ }^{7}$ & 0.17 & 0.17 & 0.17 & - \\
\hline UI mineral lactation $\operatorname{mix}^{8}$ & - & - & - & 3.70 \\
\hline Potassium carbonate & - & - & - & 0.13 \\
\hline Monensin ${ }^{9}$ & 0.02 & 0.02 & 0.02 & 0.01 \\
\hline Vitamin $\mathrm{A}^{10}$ & 0.01 & 0.01 & 0.01 & 0.03 \\
\hline${\text { Vitamin } \mathrm{D}^{11}}^{11}$ & 0.01 & 0.01 & 0.01 & 0.01 \\
\hline Vitamin $\mathrm{E}^{12}$ & 0.29 & 0.29 & 0.29 & 0.05 \\
\hline
\end{tabular}

${ }^{1}$ Control $(\mathrm{CON})$ provided a positive DCAD that averaged $+6 \mathrm{mEq} / 100 \mathrm{~g}$, targeting a urine $\mathrm{pH}$ of $>7.5$, and total dietary Ca at $0.40 \% \mathrm{DM}$; ND (negative DCAD) provided a negative DCAD that averaged $-24 \mathrm{mEq} / 100$ $\mathrm{g}$, targeting a urine $\mathrm{pH}$ of 5.5 to 6.0 , with total dietary Ca at $0.40 \% \mathrm{DM}$; and NDCA (negative DCAD plus added $\mathrm{Ca}$ ) provided a negative DCAD that averaged $-24 \mathrm{mEq} / 100 \mathrm{~g}$, targeting a urine $\mathrm{pH}$ of 5.5 to 6.0 , with total dietary Ca at $2.0 \% \mathrm{DM}$.

${ }^{2}$ Perdue Agribusiness Animal Nutrition, Salisbury, MD.

${ }^{3}$ Smartamine M, Adisseo USA Inc., Alpharetta, GA.

${ }^{4}$ AjiPro-L, Ajinomoto Animal Nutrition North America Inc., Chicago, IL.

${ }^{5}$ Composed of $38.0 \% \mathrm{CP}, 3.2 \%$ ether extract, $3.1 \%$ sugar, $5.8 \%$ starch, $15.9 \% \mathrm{NDF}, 1.4 \% \mathrm{Ca}, 0.4 \% \mathrm{P}, 4.8 \% \mathrm{Mg}$, $5.4 \% \mathrm{~S}$, and $13.9 \% \mathrm{Cl}$ (Phibro Animal Health Corp., Teaneck, NJ).

${ }^{6}$ Superflow, ADM Animal Health \& Nutrition division (Chicago, IL).

${ }^{7}$ The University of Illinois mineral and vitamin mix was formulated to contain $5 \% \mathrm{Mg}, 10 \% \mathrm{~S}, 7.5 \% \mathrm{~K}, 2.0 \%$ $\mathrm{Fe}, 3.0 \% \mathrm{Zn}, 3.0 \% \mathrm{Mn}, 5,000 \mathrm{mg} / \mathrm{kg}$ of $\mathrm{Cu}, 250 \mathrm{mg} / \mathrm{kg}$ of I, $40 \mathrm{mg} / \mathrm{kg}$ of Co, $150 \mathrm{mg} / \mathrm{kg}$ of Se, 2,200 kIU $/ \mathrm{kg}$ of vitamin $\mathrm{A}, 660 \mathrm{kIU} / \mathrm{kg}$ of vitamin $\mathrm{D}_{3}$, and $7,700 \mathrm{IU} / \mathrm{kg}$ of vitamin $\mathrm{E}$.

${ }^{8}$ The University of Illinois mineral and vitamin mix was formulated to contain $12.5 \% \mathrm{Ca}, 14.1 \% \mathrm{Na}, 9.6 \% \mathrm{Cl}$, $3.2 \% \mathrm{Mg}, 6.5 \% \mathrm{~K}, 0.19 \% \mathrm{~S}, 26.9 \mathrm{mg} / \mathrm{kg} \mathrm{Co}, 301 \mathrm{mg} / \mathrm{kg} \mathrm{Cu}, 40.2 \mathrm{mg} / \mathrm{kg} \mathrm{I}, 678 \mathrm{mg} / \mathrm{kg} \mathrm{Fe}, 1,519 \mathrm{mg} / \mathrm{kg} \mathrm{Mn}$, $8.62 \mathrm{mg} / \mathrm{kg} \mathrm{Se}, 4.47 \mathrm{mg} / \mathrm{kg}$ organic Se, $1,621 \mathrm{mg} / \mathrm{kg} \mathrm{Zn}, 43.3 \mathrm{kIU} / \mathrm{kg}$ vitamin A, $10.9 \mathrm{kIU} / \mathrm{kg}$ vitamin D3, 466.4 $\mathrm{IU} / \mathrm{kg}$ vitamin E, $4.23 \mathrm{mg} / \mathrm{kg}$ biotin, $46.6 \mathrm{mg} / \mathrm{kg}$ thiamine, and $0.35 \mathrm{~g} / \mathrm{kg}$ of monensin (Rumensin, Elanco, Greenfield, IN).

${ }^{9}$ Rumensin 80, Elanco.

${ }^{10}$ Contained 30,000 kIU/kg.

${ }^{11}$ Contained 5,009 kIU/kg.

${ }^{12}$ Contained 44,000 IU $/ \mathrm{kg}$. 
to be dropped from the trial if they calved less than 14 $\mathrm{d}$ after beginning treatment; however, no cows calved early.

Cows were grouped for treatment assignment based on expected calving date and parity (cows entering into either their second or $\geq$ third lactation), with all treatments represented in each block of 3 cows within parity groups. The treatment groups were further balanced based on previous milk production and the initial prepartum BCS. Previous milk production was obtained from PC Dart 305-d reports, and cows were divided into those above or below the herd average $(11,365 \mathrm{~kg})$. The same method was used with BCS as a binomial covariate, with cows divided based on a score of 3.5 on the 5-point dairy scoring scale (Edmondson et al., 1989). Treatments were balanced to be equally represented in high and low previous milk production and initial BCS groups.

Individual DMI was recorded daily from $50 \mathrm{~d}$ before calving through the end of the fresh period ( $\mathrm{d} 34$ postpartum), summarized by week. In the prepartum period, cows were housed in pens of 10 fitted with sand-bedded free stalls. Calan gates (American Calan) in the freestall barn were used to measure individual intakes, with offered TMR and refusals weighed daily. Cows calved in straw-bedded pens within each pen of free stalls. After calving, cows were moved to a tie-stall barn with sand-covered rubber mats. Feed was provided in individual concrete feed bunks and offered TMR and refusals were weighed daily. Following the fresh period, cows were moved at $34 \pm 1$ DIM to sand-bedded freestall barns with open lots through 73 DIM. This period was defined as the high period, and no intake measurements were made. All cows were weighed weekly and scored for BCS by 2 independent observers, whose scores were averaged for statistical analysis. Diets, orts, and individual feed ingredients were sampled once weekly and composited monthly. Composite samples were analyzed by Dairy One Forage Lab (Ithaca, NY) for complete model profile analysis.

Urine samples were collected at 27, 26, 25, and $24 \mathrm{~d}$ before expected calving and then 3 times weekly until actual calving. Postpartum urine samples were obtained on $\mathrm{d} 1,2$, and 7 . Urine $\mathrm{pH}$ was determined immediately using a portable $\mathrm{pH}$ meter and samples were frozen at $-20^{\circ} \mathrm{C}$. Blood was sampled from the coccygeal vein between 0600 and $0700 \mathrm{~h}$, before the morning feeding. Samples of whole blood were drawn in a lithium heparin tube within $1 \mathrm{~h}$ of calving, 24 and $48 \mathrm{~h}$ after calving, and 4 DIM for ionizable Ca (iCa) analysis using a portable iSTAT device with CG8+ cartridges (Abbott, Princeton, NJ). Serum was separated from blood collected in a siliconized evacuated tube at these time points and was frozen until later analysis for tCa.

Table 2. Analyzed chemical profile (mean \pm SD of monthly composite samples ${ }^{1}$ ) of the diets fed as TMR

\begin{tabular}{|c|c|c|c|c|}
\hline \multirow[b]{2}{*}{ Component } & \multicolumn{3}{|c|}{ Treatment $^{2}$} & \multirow[b]{2}{*}{ Lactation } \\
\hline & $\mathrm{CON}$ & ND & NDCA & \\
\hline $\mathrm{CP}, \%$ of DM & $15.1 \pm 1.3$ & $16.6 \pm 1.5$ & $16.4 \pm 1.0$ & $17.8 \pm 0.6$ \\
\hline $\mathrm{ADF}, \%$ of $\mathrm{DM}$ & $33.6 \pm 2.2$ & $33.9 \pm 3.6$ & $33.3 \pm 1.9$ & $18.9 \pm 1.9$ \\
\hline aNDFom, ${ }^{3} \%$ of DM & $49.3 \pm 2.6$ & $47.7 \pm 4.1$ & $46.9 \pm 4.8$ & $30.4 \pm 1.4$ \\
\hline Starch, \% of DM & $14.1 \pm 2.2$ & $12.7 \pm 2.2$ & $12.8 \pm 1.2$ & $30.8 \pm 1.5$ \\
\hline $\mathrm{NE}_{\mathrm{L}}, \mathrm{Mcal} / \mathrm{kg}$ of $\mathrm{DM}$ & $1.36 \pm 0.04$ & $1.41 \pm 0.07$ & $1.36 \pm 0.04$ & $1.58 \pm 0.02$ \\
\hline $\mathrm{Ca}, \%$ of $\mathrm{DM}$ & $0.40 \pm 0.06$ & $0.44 \pm 0.05$ & $1.97 \pm 0.6$ & $1.15 \pm 0.32$ \\
\hline $\mathrm{P}, \%$ of DM & $0.42 \pm 0.03$ & $0.43 \pm 0.04$ & $0.44 \pm 0.05$ & $0.49 \pm 0.04$ \\
\hline $\mathrm{Mg}, \%$ of $\mathrm{DM}$ & $0.43 \pm 0.08$ & $0.44 \pm 0.03$ & $0.43 \pm 0.05$ & $0.33 \pm 0.02$ \\
\hline $\mathrm{K}, \%$ of DM & $1.19 \pm 0.06$ & $1.16 \pm 0.07$ & $1.15 \pm 0.05$ & $1.48 \pm 0.1$ \\
\hline $\mathrm{Na}, \%$ of $\mathrm{DM}$ & $0.10 \pm 0.03$ & $0.08 \pm 0.02$ & $0.11 \pm 0.03$ & $0.55 \pm 0.03$ \\
\hline S, \% of DM & $0.33 \pm 0.15$ & $0.50 \pm 0.06$ & $0.52 \pm 0.04$ & $0.31 \pm 0.02$ \\
\hline DCAD, $\mathrm{mEq} / 100 \mathrm{~g}$ of DM & $6.0 \pm 9.5$ & $-24.0 \pm 6.0$ & $-24.1 \pm 5.3$ & $25.4 \pm 2.3$ \\
\hline
\end{tabular}

${ }^{1}$ Monthly composited samples included dry cow diets $(\mathrm{n}=12)$ and lactating cow diets $(\mathrm{n}=13)$.

${ }^{2} \mathrm{CON}$ provided a positive DCAD that averaged $+6 \mathrm{mEq} / 100 \mathrm{~g}$, targeting a urine $\mathrm{pH}$ of $>7.5$, and total dietary Ca at $0.40 \%$ DM; ND (negative DCAD) provided a negative DCAD that averaged $-24 \mathrm{mEq} / 100 \mathrm{~g}$, targeting a urine $\mathrm{pH}$ of 5.5 to 6.0 , with total dietary Ca at $0.40 \%$ DM; and NDCA (negative DCAD plus added Ca) provided a negative DCAD that averaged $-24 \mathrm{mEq} / 100 \mathrm{~g}$, targeting a urine pH of 5.5 to 6.0 , with total dietary $\mathrm{Ca}$ at $2.0 \% \mathrm{DM}$.

${ }^{3}$ aNDFom $=$ amylase-determined neutral detergent fiber, OM basis. 
At calving, colostrum was collected, weighed, and sampled. Both cow and calf were weighed on the day of calving. Colostrum samples, defined as the cow's first milk after calving, were frozen at $-20^{\circ} \mathrm{C}$. The $\mathrm{IgG}$ concentrations were determined by Prairie Diagnostic (Saskatoon, SK, Canada) in a single radial immunodiffusion assay. After calving, all cows consumed the same lactation diet (Tables 1 and 2) and were milked 3 times daily at 0600,1400 , and 2100 h. Daily milk yields were recorded. Milk samples were collected once weekly during the fresh period from 3 consecutive milkings and composited in proportion to milk yield at each sampling. The samples, preserved using Broad Spectrum Microtabs II (San Ramon, CA), were shipped to Dairy Lab Services (Dubuque, IA) and analyzed for milk components by mid-infrared techniques. Both FCM and ECM were calculated (Orth, 1992; Bethard, 2012).

Health incidents and all medical treatments were recorded. An adverse health event score was calculated using numerical values assigned to each health event, based on Nace et al. (2014). Scored values included no event $=0$, ketosis $=2$, retained placenta $=2$, displaced abomasum $=3$, milk fever $=2$, diarrhea $=2$, udder edema $=1$, fever $=1$, mastitis $=3$, metritis $=2$, and euthanized $=5$. The occurrence of $\mathrm{SCH}$ was determined retrospectively, based on $\mathrm{iCa}$ and tCa results. The SCH threshold for iCa was $\leq 1.0 \mathrm{mM}$ at $24 \mathrm{~h}$ after calving, based on altered metabolism and impaired immune function observed by Martinez et al. (2014). The threshold for tCa was $\leq 2.125 \mathrm{~m} M$ at $48 \mathrm{~h}$ after calving, based on its correlation with related metabolic health disorders (Chapinal et al., 2012; Martinez et al., 2012; Leno et al., 2017).

The prepartum period was divided retrospectively into 3 sub-periods based on actual calving date. The far-off period was defined as the 2 wk when cows were enrolled and were fed the CON diet as a baseline. The adaptation period was a 2 -wk period that encompassed cows transitioning between the far-off and close-up treatment periods, based on the variation of time between the initial start date and their actual calving date. All cows assigned to ND or NDCA were consuming a negative DCAD diet at least $2 \mathrm{~d}$ before the end of the adaptation period. The close-up period was defined as the 3 wk before calving, when all cows were successfully adapted to their respective dietary treatments. All cows calved within $7 \mathrm{~d}$ of expected calving, and average days the treatment diets were consumed were CON, 28 $\pm 0.4 \mathrm{~d} ; \mathrm{ND}, 28 \pm 0.7 \mathrm{~d}$; and NDCA, $28 \pm 0.9 \mathrm{~d}$.

Production variables and blood $\mathrm{Ca}$ data were analyzed in a mixed model using SAS 9.4. All cows remained in the data set unless medical intervention was required, such as Ca therapy for milk fever. Data for the far-off, close-up, fresh, and high periods were analyzed separately. The production model included fixed effects of treatment, time, and treatment by time interaction, the random effect of block, a repeated variable of week or sample day with cow as the subject, and covariates of initial BCS and previous lactation SCC. Binomial covariates of parity and previous milk production (i.e., high or low), used in the initial blocking of cows entering the study, also were tested in the full model, but were removed from the simple model as non-significant $(P>0.20)$. The Ca status model also tested these covariates and only parity was included in the simple model. A median adjustment was applied to BW and BCS for the pre- and postpartum periods to reduce the error of scale variability and weekly subjective bias of BCS. The median function was used continuously over 3 consecutive weekly samples for each individual animal. Respectively: first-order autoregressive, compound symmetry, unstructured, heterogeneous first-order autoregressive, and heterogeneous compound symmetry covariance structures were tested in our model for repeated variables and first-order autoregressive was selected based on the smallest value of Akaike's information criterion, corrected Akaike's information criterion, and Bayesian information criterion. A frequency model with a Pearson chi-squared was used to compare clinical health events. A sample size of 25 cows per treatment was determined by a power test, at a 0.05 $\alpha$ level, to detect a $5 \%$ milk production difference with greater than $90 \%$ power.

Two preplanned orthogonal contrast statements were constructed to compare dietary interventions (DCAD and dietary $\mathrm{Ca}$ ) on production and health. The first contrast, CON versus (ND and NDCA), compares the low Ca strategy in the CON diet to the upregulation of homeostatic mechanisms for Ca created by compensated metabolic acidosis in the 2 acidogenic diets (ND and NDCA). Both strategies stimulate Ca mobilization before calving. The second contrast, ND versus NDCA, compared the effect of dietary Ca concentration within a negative DCAD strategy, either relying heavily on bone $\mathrm{Ca}$ resorption or supplying additional absorbed dietary $\mathrm{Ca}$ to be added to the circulating $\mathrm{Ca}$ pool. Significance was declared at $P \leq 0.05$ and trends were discussed when $0.05<P \leq 0.10$.

\section{RESULTS AND DISCUSSION}

\section{Inclusion and Exclusion of Cows}

A total of 83 cows were assigned to prepartum treatment diets in this study. Two cows calved with undiagnosed twins, and their data were not used in analyses. A total of 81 cows calved on the study $(\mathrm{CON}=28$; $\mathrm{ND}=27$; NDCA $=26$ ). Blood samples for Ca status 
were included in the analysis up to the time when cows were diagnosed with and treated for clinical hypocalcemia $(\mathrm{ND}=2$ at $24 \mathrm{~h} ; \mathrm{CON}=2$ and $\mathrm{ND}=1$ at 48 h) and data from those cows were excluded thereafter. For postpartum production, clinical hypocalcemic cows were excluded $(\mathrm{CON}=2, \mathrm{ND}=3, \mathrm{NDCA}=0)$, and 4 cows were euthanized or died during the fresh period $(\mathrm{CON}=2, \mathrm{ND}=2, \mathrm{NDCA}=0)$. Of the 2 cows fed CON that died, 1 was euthanized for toxic mastitis at 3 DIM, and the other died suddenly of unknown causes at 9 DIM. Of the 2 cows fed ND that died, 1 was euthanized for clinical ketosis at 3 DIM, and the other was euthanized after falling in the parlor at 11 DIM. Additionally, the 2 cows fed CON diagnosed with clinical hypocalcemia were later euthanized, 1 for developing nervous ketosis and the other for organ failure. In the high period, 2 cows fed CON were euthanized, both for a recurring displaced abomasum.

\section{Urine $\mathrm{pH}$ and DCAD}

Dietary treatments ND and NDCA were formulated to maintain urine $\mathrm{pH}$ at 5.5 to 6.0 , compared with expected $\mathrm{pH}$ in cows fed $\mathrm{CON}$ of $>7.5$. All cows fed
$\mathrm{ND}$ and NDCA reached this urine $\mathrm{pH}$ range within $48 \mathrm{~h}$ after starting the treatment diet, and urine $\mathrm{pH}$ remained consistent throughout the prepartum period (Figure 1). As designed, prepartum urine $\mathrm{pH}$ was different when comparing CON (8.11) against ND and NDCA $(5.75 \pm 0.06 ; P<0.01)$. There was no difference in urine $\mathrm{pH}$ between the 2 acidogenic treatments. By $48 \mathrm{~h}$ after calving, no cow had acidic urine $\mathrm{pH}$ $(<7.0)$, indicating a rapid return to a normal metabolic acid-base balance when fed the lactation diet. These urine samples were used to mark the cows' response to the treatment diets, but also were used as a feed management tool to determine if adjustments were needed to maintain desired urine $\mathrm{pH}$. Urine $\mathrm{pH}$ was taken at a consistent time each day, directly before feeding, for these calculations. Lower-than-expected dietary DCAD levels were required in ND and NDCA formulations, with approximately $-24 \mathrm{mEq} / 100 \mathrm{~g}$ of DM needed to achieve the desired response of urine $\mathrm{pH}$ from the cows (Table 2). The initial formulation began at $-15 \mathrm{mEq} / 100 \mathrm{~g}$ of $\mathrm{DM}$ provided to the first cow enrolled, but was adjusted through a reformulation of the premixed concentrate within $48 \mathrm{~h}$ to achieve the desired urine $\mathrm{pH}$ range.

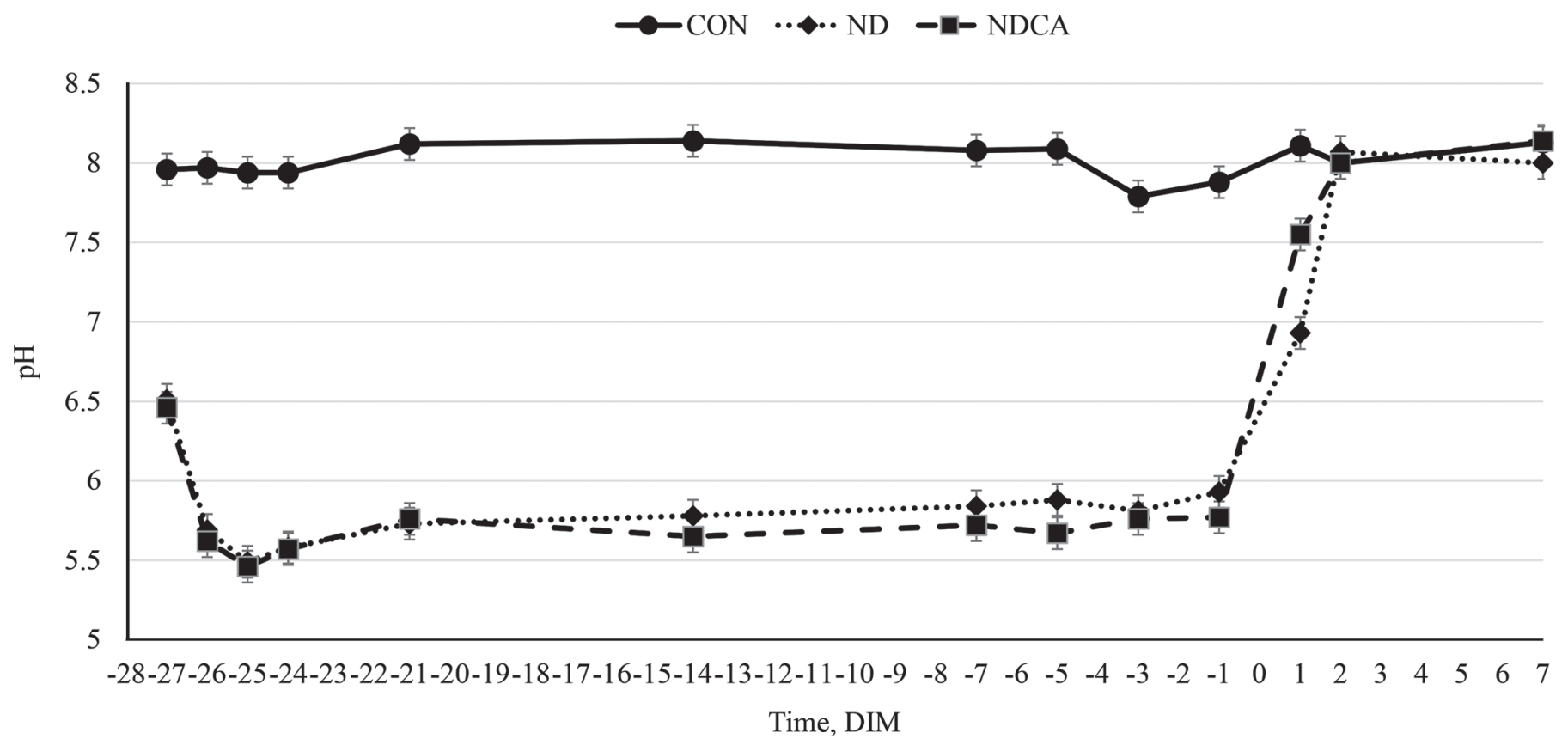

Figure 1. Least squares means and SE bars for urine $\mathrm{pH}$ values over the prepartum and postpartum periods for cows fed prepartum dietary treatments: CON (control) provided a positive DCAD that averaged $+6 \mathrm{mEq} / 100 \mathrm{~g}$, targeting a urine $\mathrm{pH}$ of $>7.5$, and total dietary Ca at $0.40 \%$ $\mathrm{DM}$; ND (negative DCAD) provided a negative DCAD that averaged $-24 \mathrm{mEq} / 100 \mathrm{~g}$, targeting a urine $\mathrm{pH}$ of 5.5 to 6.0 , with total dietary Ca at $0.40 \% \mathrm{DM}$; and NDCA (negative DCAD plus added Ca) provided a negative DCAD that averaged $-24 \mathrm{mEq} / 100 \mathrm{~g}$, targeting a urine $\mathrm{pH}$ of 5.5 to 6.0 , with total dietary Ca at $2.0 \%$ of DM. Animate supplementation (Phibro Animal Health Corp., Teaneck, NJ) was used to alter the prepartum DCAD and calcium carbonate was the source of additional Ca. The initial 4 sampling times were taken daily starting the day after treatment began, based on expected calving date, and the other sampling times were based on the retrospective calculation from the actual calving date. Contrast CON versus (ND and NDCA): prepartum, $P<0.01$ and postpartum, $P<0.01$. Contrast ND versus NDCA: prepartum, $P=0.37$ and postpartum, $P=0.04$. Treatment by time interaction: prepartum, $P=0.69$ and postpartum, $P<0.01$. 
Many past studies have explored the use of negative DCAD diets but focused solely on the analysis of the diets and not the urine $\mathrm{pH}$ values that would represent the direct response from the cow (Lean et al., 2006; Oetzel, 1991). Other reviews have sought to connect the linear and quadratic effects of DCAD on the biological response of decreasing urine $\mathrm{pH}$ to the benefits of the DCAD strategy (Charbonneau et al., 2006; Santos et al., 2019). This relationship was highlighted in the statistical approach of Santos et al. (2019) by removing the DCAD effect and using urine $\mathrm{pH}$ as a linear and quadratic covariate to better understand the relationship between urine $\mathrm{pH}$ and the risk of milk fever. When using the level of DCAD in the analysis, there was a quadratic effect on the risk of milk fever, but when urine $\mathrm{pH}$ was used, there was a linear and quadratic effect on the same variable (Santos et al., 2019). The inference that DCAD has both a linear and quadratic relationship with urine $\mathrm{pH}$, as shown by Santos et al. (2019), did not account for differences among herds or regions that may affect responses of individual cows to an acidogenic diet. Leno et al. (2017) reported urine $\mathrm{pH}<6.0$ with a DCAD of $-7.4 \mathrm{mEq} / 100 \mathrm{~g}$ of DM, whereas the current study required almost 3 times that to achieve the same results $(-24 \mathrm{mEq} / 100 \mathrm{~g}$ of $\mathrm{DM})$. Therefore, continued emphasis should be placed on measuring prepartum compensated metabolic acidosis through a biological marker (urine $\mathrm{pH}$ ), rather than on the DCAD measurement in the diet alone.

The degree of acidification in prepartum diets needed to reduce the risk of milk fever has been a point of controversy. Goff and Koszewski (2018) explored this concern as an objective, combined with the amount of dietary Ca needed in the prepartum diet. They compared treatments of $0.46 \%$ dietary Ca with a positive DCAD, with urine $\mathrm{pH}$ of $8.27 ; 0.46 \%$ dietary Ca with a negative DCAD, with urine $\mathrm{pH}$ of 7.0 ; and $0.72 \%$ $\mathrm{Ca}$ with the same negative DCAD, with urine $\mathrm{pH}$ of 7.41. The authors concluded that $0.46 \%$ dietary Ca was not low enough to improve postpartum Ca status and that, when high dietary $\mathrm{Ca}$ is fed, additional anions are needed to overcome the alkalinizing effect of this cation (Goff and Koszewski, 2018). Charbonneau et al. (2006) cautioned against lowering urine $\mathrm{pH}$ below 7.0 because of the effect on prepartum DMI, but did not separate the use of straight salts and commercially balanced anionic products fed among the reviewed studies. Santos et al. (2019) proposed in their conclusion that a negative DCAD probably does not need to be below $-15 \mathrm{mEq} / 100 \mathrm{~g}$ of $\mathrm{DM}$, but did not offer a specific urine $\mathrm{pH}$ range. It was estimated that a DCAD between -20 and $-10 \mathrm{mEq} / 100 \mathrm{~g}$ of DM was needed to achieve urine pH of 5.5 to 6.5 (Santos et al., 2019).
Grünberg et al. (2011) explored the relationship between urinary $\mathrm{Ca}$ excretion and urine $\mathrm{pH}$ in prepartal cows fed an acidogenic diet. Urine $\mathrm{pH}$ and urine net acid excretion, which is an important indicator of acidbase homeostasis, have a nonlinear relationship that is not consistent when urine $\mathrm{pH}$ is $<6.3$ (Constable et al., 2009). However, a strong negative linear relationship exists between urine $\mathrm{pH}$ and the urinary Ca-creatinine ratio, indicating that the success of the acidogenic prepartum strategy relies on an increase in Ca flux (Grünberg et al., 2011). Goff and Koszewski (2018) noted that their study, which did not result in urine $\mathrm{pH}$ below 6.8 , would not have shown appreciable increases in urinary $\mathrm{Ca}$ excretion. They suggested a future study include a low dietary Ca diet with a target urine $\mathrm{pH}$ of 5.5 to 6.0 to create a negative Ca balance in prepartum cows. The increased movement of $\mathrm{Ca}$ in and out of the exchangeable Ca pool, via absorption from the diet, resorption from the labile portion of bone, and excretion in the urine, does not decrease the size of the Ca pool in the prepartum period. Rather, the amount of Ca that was excreted in the urine before calving is thought to be readily available at the start of lactation. At calving, urine $\mathrm{pH}$ rapidly increases, and urinary Ca excretion decreases to $<1 \mathrm{~g} / \mathrm{d}$. This Ca can then be used by the mammary gland for initial milk production (Grünberg et al., 2011). By this assumption, the more Ca that is excreted in the urine prepartum, the more $\mathrm{Ca}$ will be available to the cow at the time of calving, independent of dietary $\mathrm{Ca}$ intake.

\section{Prepartum Period}

During the far-off period (Table 3), cows assigned to the CON treatment diet had greater BCS than cows assigned to ND or NDCA treatment diets $(P=0.01)$. This difference resulted from the pretrial blocking for BCS that assigned a binomial value of whether the cow was above or below 3.5 at the time of enrollment. Along with the greater BCS, cows fed $\mathrm{CON}$ also tended to have greater BW $(P=0.07)$ during the far-off period. The BCS and BW did not differ between cows later fed ND or NDCA. The differences in BW and BCS observed during the far-off period continued to be significantly different in the close-up period for cows fed CON (814 kg and 3.93, respectively) compared with those fed ND or NDCA $(789 \pm 5.9 \mathrm{~kg}$ and $3.79 \pm 0.04$; $P<0.01$ ), although the biological significance of these small differences is questionable.

During the adaptation period, DMI $(\mathrm{kg} / \mathrm{d})$ fluctuated (Figure 2), increasing the standard error from 0.18 to 0.41 as the cows became acclimated to their treatment diets. Cows that were switched to ND and NDCA had 
Table 3. Least squares means for DMI, BW, and BCS during the prepartum period for cows fed close-up dietary treatments CON, ND, or NDCA, starting at -28 d relative to expected calving

\begin{tabular}{|c|c|c|c|c|c|c|c|}
\hline \multirow[b]{2}{*}{ Variable } & \multicolumn{3}{|c|}{ Treatment $(\text { Trt })^{1}$} & \multirow[b]{2}{*}{$\mathrm{SE}$} & \multirow[b]{2}{*}{ Trt $\times$ Time } & \multicolumn{2}{|c|}{ Contrast $^{2}$} \\
\hline & $\mathrm{CON}(\mathrm{n}=28)$ & $\mathrm{ND}(\mathrm{n}=27)$ & NDCA $(\mathrm{n}=26)$ & & & 1 & 2 \\
\hline \multicolumn{8}{|c|}{ Far-off ${ }^{3}(-7$ to -6 wk $)$} \\
\hline DMI, kg/d & 13.0 & 12.7 & 13.1 & 0.2 & 0.94 & 0.63 & 0.08 \\
\hline DMI, $\%$ of BW & 1.68 & 1.63 & 1.83 & 0.07 & 0.77 & 0.49 & 0.02 \\
\hline Ca intake, $\mathrm{g} / \mathrm{d}$ & 50.3 & 46.3 & 53.2 & 2.4 & 0.95 & 0.80 & 0.01 \\
\hline $\mathrm{BW}, \mathrm{kg}$ & 789 & 779 & 783 & 4 & 0.18 & 0.07 & 0.52 \\
\hline DMI, kg/d & 13.8 & 11.7 & 12.5 & 0.4 & 0.01 & $<0.01$ & 0.12 \\
\hline DMI, $\%$ of BW & 1.75 & 1.50 & 1.67 & 0.07 & 0.01 & 0.02 & 0.04 \\
\hline Ca intake, g/d & 52.5 & 48.2 & 142.5 & 5.9 & $<0.01$ & $<0.01$ & $<0.01$ \\
\hline $\mathrm{BW}, \mathrm{kg}$ & 805 & 787 & 793 & 5 & 0.11 & 0.02 & 0.38 \\
\hline $\mathrm{BCS}$ & 3.93 & 3.76 & 3.84 & 0.04 & 0.66 & $<0.01$ & 0.12 \\
\hline \multicolumn{8}{|c|}{ Close-up ${ }^{5}$ ( -3 wk to calving) } \\
\hline DMI, kg/d & 12.0 & 10.0 & 11.0 & 0.4 & 0.84 & $<0.01$ & 0.10 \\
\hline
\end{tabular}

${ }^{1} \mathrm{CON}$ provided a positive dietary cation-anion difference (DCAD) that averaged $+6 \mathrm{mEq} / 100 \mathrm{~g}$, targeting a urine $\mathrm{pH}$ of $>7.5$, and total dietary $\mathrm{Ca}$ at $0.40 \% \mathrm{DM}$; ND (negative DCAD) provided a negative DCAD that averaged $-24 \mathrm{mEq} / 100 \mathrm{~g}$, targeting a urine $\mathrm{pH}$ of 5.5 to 6.0 , with total dietary Ca at $0.40 \% \mathrm{DM}$; and NDCA (negative DCAD plus added Ca) provided a negative DCAD that averaged $-24 \mathrm{mEq} / 100 \mathrm{~g}$, targeting a urine $\mathrm{pH}$ of 5.5 to 6.0 , with total dietary $\mathrm{Ca}$ at $2.0 \% \mathrm{DM}$.

${ }^{2}$ The preplanned contrast statements were (1) CON vs. the average of ND and NDCA, and (2) ND vs. NDCA.

${ }^{3}$ All groups were fed the CON diet from dry-off until treatment initiation.

${ }^{4}$ All cows were given their assigned treatment diets, either remaining on CON or starting ND or NDCA, at -4 wk relative to expected calving. Based on the actual calving date, the adaptation period was back calculated as 5 and 4 wk before actual calving, as all cows calved within $7 \mathrm{~d}$ of their expected calving date.

${ }^{5}$ The close-up period began 3 wk before calving, when all cows were consuming their respective dietary treatments.

decreased $(P<0.01)$ DMI $(\mathrm{kg} / \mathrm{d})$ compared with cows fed CON. Cows fed CON did not change diets from the far-off period.

In the close-up period, cows fed the CON diet had greater DMI $(\mathrm{kg} / \mathrm{d})$ than cows fed ND or NDCA $(12.0$ vs. $10.5 \pm 0.41 \mathrm{~kg} / \mathrm{d} ; P<0.01)$. Cows fed CON tended to have greater DMI as a percentage of BW (1.51\%) than cows fed ND or NDCA $(1.38 \pm 0.06 \%$ of BW; $P=$ 0.06). Cows fed CON also decreased DMI approaching calving, similar to the cows fed ND or NDCA. Calcium intake averaged 45.2 and $43.4 \mathrm{~g} / \mathrm{d}$ for the low-Ca diets CON and ND, respectively. Goff and Koszewski (2018) calculated, based on Ca bioavailability and absorption, a diet less than $57 \mathrm{~g} / \mathrm{d}$ would be below the requirements of a mature dry cow. The Ca intakes in this study are in the range of diets shown by others to be protective against hypocalcemia (Oetzel, 1991; Liesegang et al., 2007). Intake of Ca for cows fed NDCA was $226.6 \mathrm{~g} / \mathrm{d}$, which was significantly greater than that for ND as designed.

Decreased DMI in the prepartum period is a concern when feeding an acidogenic diet. A recent study reported that DMI, both as $\mathrm{kg} / \mathrm{d}$ and percentage of BW, was decreased by metabolic acidosis, but could be further decreased by less palatable anionic sources
(Zimpel et al., 2018). The number of anionic sources tested in that study was limited and did not include the source we used. In our study, cows fed NDCA tended to have greater DMI $(11.0 \mathrm{~kg} / \mathrm{d})$ than cows fed ND $(10.0 \mathrm{~kg} / \mathrm{d})$ and had greater DMI as a percentage of BW than cows fed ND $(P=0.04)$. However, the cows that consumed NDCA also tended to have greater DMI and had greater DMI as a percentage of BW than ND during the far-off period when consuming the same diet as ND cows. Decreases in DMI from far-off to close-up periods were similar for ND and NDCA.

A case can be made that supplemental $\mathrm{Ca}$ might favor greater DMI when cows are fed acidogenic diets. Zimpel et al. (2018) concluded that adding a strong alkalogenic salt that resulted in a positive DCAD in the prepartum diet prevented prepartum depression of DMI. Calcium, as a divalent cation, normally is not included in DCAD calculations, but when supplemented in the NDCA treatment was associated with greater DMI compared with ND. Martinez et al. (2014) demonstrated the important role of $\mathrm{Ca}$ on rumen motility by inducing SCH in lactating cows and measuring rumen contractions and DMI. They found limiting Ca availability to the smooth muscles of the digestive system reduced gut movement and DMI. Such a mechanism 
might explain increased DMI in cows fed additional Ca compared with restricted dietary Ca within negative DCAD strategies. Additional research should verify whether there is an advantage to added Ca for maintaining DMI if feeding acidogenic diets.

Our data support the idea that through the Ca flux mechanism, the opportunity exists to provide additional dietary Ca for relevant functions, such as smooth muscle contraction within the digestive system, without interfering in the stimulation of the PTH pathway (Lean et al., 2013; Leno et al., 2017). Because additional dietary $\mathrm{Ca}$ is excreted in the urine, benefits of compensated metabolic acidosis prepartum can be maintained while providing adequate available $\mathrm{Ca}$ from the diet for $\mathrm{Ca}$ dependent functions. The ideal formulation range of the negative DCAD and the amount of dietary Ca for an optimal Ca response continues to be debated (Chan et al., 2006; Weich et al., 2013; Santos et al., 2019). Goff and Koszewski (2018) explored differing levels of dietary Ca and DCAD and found that increasing dietary Ca from $0.46 \%$ to $0.72 \%$ with the same DCAD increased urine $\mathrm{pH}$ from 7.0 to 7.4, effectively mitigating the effect of the anionic sources on compensated metabolic acidosis.
However, when targeting a urine $\mathrm{pH}$ of 5.5 to 6.0 , Leno et al. (2017) suggested a fundamental change in Ca homeostatic regulation, based on their results of drastically increased urinary $\mathrm{Ca}$ excretion prepartum. Our findings support ideas proposed by Leno et al. (2017), including greater urinary Ca excretion prepartum (K. M. Glosson, unpublished data; Glosson, 2018).

At parturition, BW continued to be different among treatments (Table 4), with cows fed CON during the prepartum period calving at a greater BW than cows fed ND or NDCA $(P=0.02)$. Calf birth weight, calving difficulty score, colostrum weight, and colostral IgG concentration did not differ among treatments (Table 4). Effects on colostrum are a prevalent concern that has been addressed in earlier work, such as Diehl et al. (2018).

\section{Postpartum Ca Status}

The success of the acidogenic prepartum strategies tested here was measured through serum Ca concentrations postpartum. The correlation between serum tCa and blood iCa is not consistent around the time

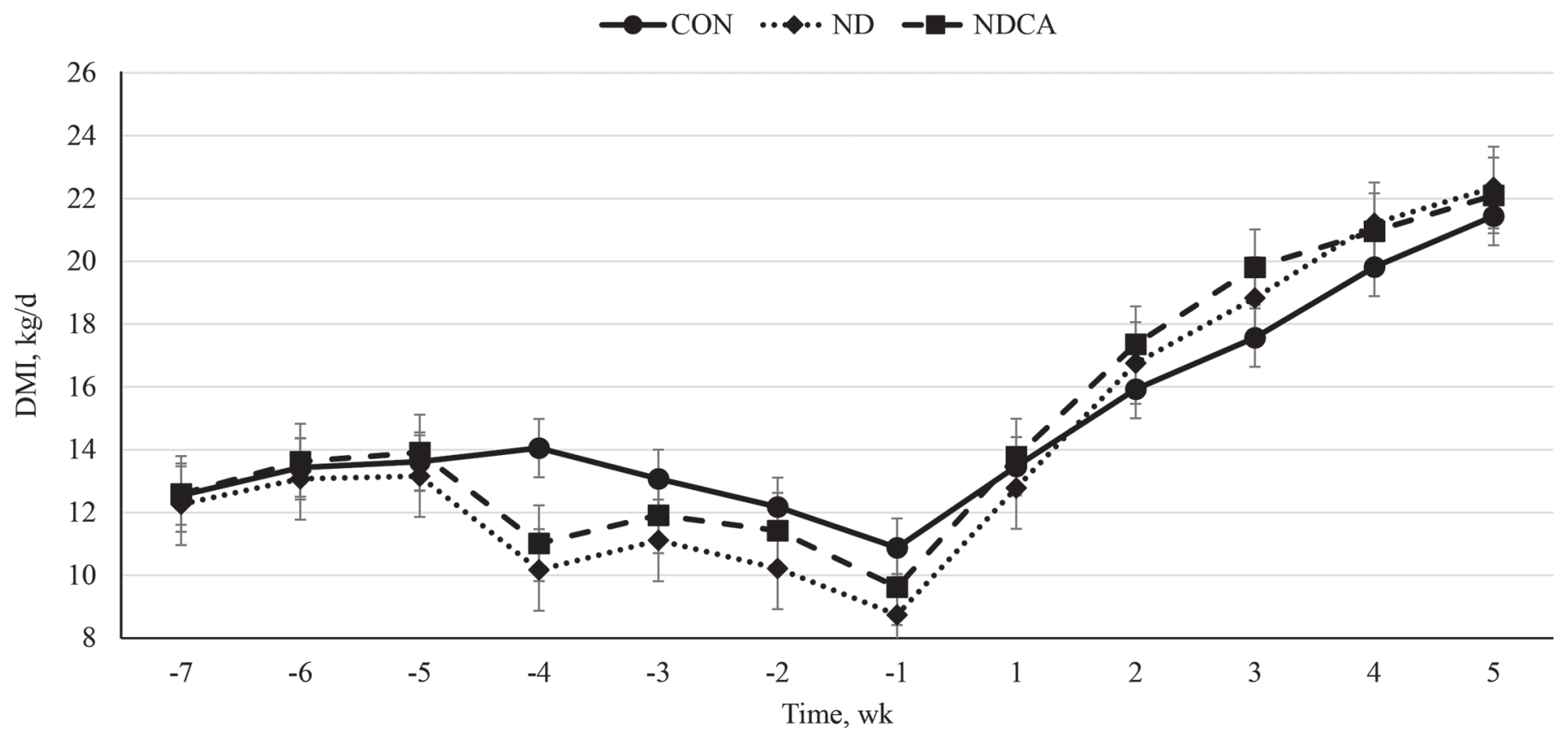

Figure 2. Least squares means and SE bars for DMI during the dry period for cows fed prepartum dietary treatments: CON (control) provided a positive DCAD that averaged $+6 \mathrm{mEq} / 100 \mathrm{~g}$, targeting a urine $\mathrm{pH}$ of $>7.5$, and total dietary Ca at 0.40\% DM; ND (negative DCAD) provided a negative DCAD that averaged $-24 \mathrm{mEq} / 100 \mathrm{~g}$, targeting a urine $\mathrm{pH}$ of 5.5 to 6.0 , with total dietary Ca at $0.40 \% \mathrm{DM}$; and NDCA (negative DCAD plus added Ca) provided a negative DCAD that averaged $-24 \mathrm{mEq} / 100 \mathrm{~g}$, targeting a urine $\mathrm{pH}$ of 5.5 to 6.0 , with total dietary $\mathrm{Ca}$ at $2.0 \%$ DM. Animate supplementation (Phibro Animal Health Corp., Teaneck, NJ) was used to alter the prepartum DCAD and calcium carbonate was the source of additional Ca. The dry period was separated into the far-off period (wk -6 to -7 ), the start of the treatment diet retrospectively calculated based on actual calving date ( $\pm 7 \mathrm{~d}$ of expected calving; wk -4 to -5$)$, and the close-up period with all cows consuming assigned treatment diets ( $\mathrm{wk}-1$ to -3 ). Contrast CON versus (ND and NDCA): close-up period, $P<0.01$ and fresh period, $P<0.22$. Contrast ND versus NDCA: close-up, $P=0.10$ and fresh period, $P=0.65$. Treatment by time interaction: close-up period, $P=0.83$ and fresh period, $P=0.29$. 
of calving (Russell and Roussel, 2007). The state of compensated metabolic acidosis induced by feeding an acidogenic diet has been shown to dissociate proteinbound $\mathrm{Ca}$ and increase the percentage of $\mathrm{iCa}$ in $\mathrm{tCa}$ (Joyce et al., 1997). Another convoluting factor involves the intracellular stores of $\mathrm{iCa}$ within the endoplasmic reticulum that can be depleted to maintain circulating $\mathrm{Ca}$, separate from the extracellular pool (Bréchard and Tschirhart, 2008). Both of these considerations obscure the accurate evaluation of tCa as a direct indicator of the $\mathrm{iCa}$ available to periparturient cows. Therefore, both tCa and iCa should be evaluated to determine the Ca status of transition cows.

Sampling time is important in assessing hypocalcemia, as high-producing cows may deplete their initial Ca reserves at the time of calving to support milk production, but can recover through homeorhetic mechanisms (Neves et al., 2018). Therefore, we used reported thresholds for both iCa and tCa at $24 \mathrm{~h}$ and $48 \mathrm{~h}$ after calving, respectively. Any delay in endocrine signaling to replenish the available Ca pool at the time of calving can result in detrimental effects on postpartum milk production and health. The endocrine system influences $\mathrm{Ca}$ movement directly from digestive absorption, urinary reabsorption, and bone resorption (Overton and Waldron, 2004). Consequently, the established thresholds at specific sampling times are markers of the success of Ca homeostasis via signaling and responsiveness through the endocrine system.

Results from the iSTAT device and tCa are shown in Table 5. Directly after calving, cows fed CON prepartum had lower $(P<0.01) \mathrm{iCa}$ and $\mathrm{tCa}$ than cows fed ND or NDCA for both. However, Ca status at the time of calving has not been associated with adverse health events (McArt and Neves, 2019). At $24 \mathrm{~h}$ after calving,
iCa was lower for cows fed CON than ND or NDCA (0.98 vs. $1.08 \pm 0.03 \mathrm{~m} M ; P<0.01)$. Mean iCa for cows fed CON was below the established cut-off of $1.0 \mathrm{~m} M$ at $24 \mathrm{~h}$ and would be considered SCH. Cows fed ND or NDCA averaged above the threshold and did not differ between treatments. As a percentage of cows within the treatment groups, $43 \%$ of cows fed CON, $20 \%$ of cows fed ND, and $35 \%$ of cows fed NDCA were considered SCH by using iCa. Parity also was significant in the model for iCa at $24 \mathrm{~h}$. Older animals ( $\geq 3$ lactations) had greater iCa concentration $(1.12 \mathrm{mM})$ than cows in their 2nd lactation $(0.97 \mathrm{mM})$. As cows age, Ca resorption from bone sources decreases due to a reduced responsiveness to hormonal signals and decrease in labile bone fraction (Horst et al., 2005). By 48 h after calving, iCa no longer differed among treatments.

At $48 \mathrm{~h}$ after calving, cows fed CON $(2.02 \mathrm{mM})$ were below the $2.12 \mathrm{mM}$ tCa threshold for $\mathrm{SCH}$ and significantly lower than cows fed ND or NDCA $(2.16 \pm 0.04$ $\mathrm{m} M ; P=0.04)$. There was no difference between cows fed ND or NDCA. As a percentage of cows, $63 \%$ of cows fed CON, $48 \%$ of cows fed ND, and $46 \%$ of cows fed NDCA fell below the tCa threshold. Older cows again had a greater Ca status as shown by tCa at $48 \mathrm{~h}$ $(2.20 \mathrm{~m} M$ vs. $2.05 \mathrm{mM})$. At $4 \mathrm{DIM}$, there was no difference in $\mathrm{iCa}$ or tCa related to the prepartum dietary treatments. Summarily, using iCa at $24 \mathrm{~h}$ after calving and tCa at $48 \mathrm{~h}$ after calving, both acidogenic diets, regardless of additional dietary $\mathrm{Ca}$, were successful in improving postpartum Ca status.

Both DCAD concentration and dietary Ca have been shown to impact Ca status (Moore et al., 2000, Amundson et al., 2018). Moore et al. (2000) compared: 1) a diet with positive prepartum $\mathrm{DCAD},+15 \mathrm{mEq} / 100 \mathrm{~g}$ of DM with a urine $\mathrm{pH}$ of $7.95 ; 2$ ) a diet with zero DCAD,

Table 4. Least squares means for calving data for cows fed close-up dietary treatments CON, ND, or NDCA starting at $-28 \mathrm{~d}$ relative to expected calving

\begin{tabular}{|c|c|c|c|c|c|c|}
\hline \multirow[b]{2}{*}{ Variable } & \multicolumn{3}{|c|}{ Treatment $(\text { Trt })^{1}$} & \multirow[b]{2}{*}{$\mathrm{SE}$} & \multicolumn{2}{|c|}{ Contrast $^{2}$} \\
\hline & $\mathrm{CON}(\mathrm{n}=28)$ & $\mathrm{ND}(\mathrm{n}=27)$ & NDCA $(\mathrm{n}=26)$ & & 1 & 2 \\
\hline Calf BW, kg & 44.0 & 43.5 & 44.4 & 0.8 & 0.99 & 0.39 \\
\hline Calving difficulty $^{3}$ & 1.2 & 1.2 & 1.2 & 0.1 & 0.82 & 0.79 \\
\hline Colostrum ${ }^{4} \mathrm{~kg}$ & 5.05 & 4.31 & 4.29 & 0.51 & 0.19 & 0.98 \\
\hline Colostrum ${ }^{4} \operatorname{IgG}, \mathrm{mg} / \mathrm{mL}$ & 88.8 & 87.2 & 88.6 & 6.0 & 0.90 & 0.87 \\
\hline
\end{tabular}

${ }^{1} \mathrm{CON}$ provided a positive dietary cation-anion difference (DCAD) that averaged $+6 \mathrm{mEq} / 100 \mathrm{~g}$, targeting a urine $\mathrm{pH}$ of $>7.5$, and total dietary $\mathrm{Ca}$ at $0.40 \% \mathrm{DM}$; ND (negative DCAD) provided a negative DCAD that averaged $-24 \mathrm{mEq} / 100 \mathrm{~g}$, targeting a urine $\mathrm{pH}$ of 5.5 to 6.0 , with total dietary Ca at $0.40 \% \mathrm{DM}$; and NDCA (negative DCAD plus added Ca) provided a negative DCAD that averaged $-24 \mathrm{mEq} / 100 \mathrm{~g}$, targeting a urine $\mathrm{pH}$ of 5.5 to 6.0 , with total dietary $\mathrm{Ca}$ at $2.0 \% \mathrm{DM}$.

${ }^{2}$ The preplanned contrast statements were (1) CON vs. the average of ND and NDCA and (2) ND vs. NDCA.

${ }^{3}$ Calving difficulty scoring: 1 = easy calving with no assistance needed; $2=$ calving needing minimum assistance; $3=$ complicated calving with invasive assistance needed.

${ }^{4}$ Colostrum defined as the first milking only. 
Table 5. Least squares means for postpartum blood analysis for cows fed close-up dietary treatments CON, ND, or NDCA, starting at $-28 \mathrm{~d}$ relative to expected calving ${ }^{1}$

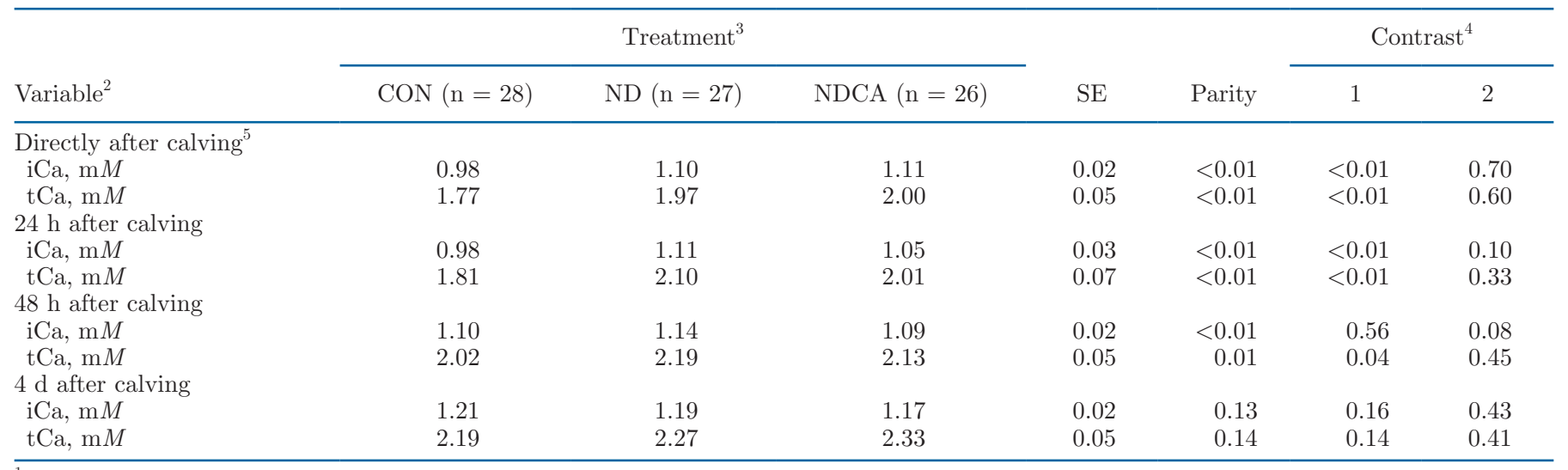

${ }^{1}$ Blood samples for Ca status were included up to diagnoses and treatment for clinical hypocalcemia. The excluded cows were diagnosed within $48 \mathrm{~h}$ after calving but after the initial sample was taken $(\mathrm{ND}=2$ at $24 \mathrm{~h}$; $\mathrm{CON}=2, \mathrm{ND}=1$ at $48 \mathrm{~h})$.

${ }^{2} \mathrm{iCa}=$ ionized calcium; $\mathrm{tCa}=$ total calcium

${ }^{3} \mathrm{CON}$ provided a positive dietary cation-anion difference (DCAD) that averaged $+6 \mathrm{mEq} / 100 \mathrm{~g}$, targeting a urine $\mathrm{pH}$ of $>7.5$, and total dietary $\mathrm{Ca}$ at $0.40 \% \mathrm{DM}$; ND (negative DCAD) provided a negative DCAD that averaged $-24 \mathrm{mEq} / 100 \mathrm{~g}$, targeting a urine $\mathrm{pH}$ of 5.5 to 6.0 , with total dietary $\mathrm{Ca}$ at $0.40 \% \mathrm{DM}$; and NDCA (negative DCAD plus added Ca) provided a negative DCAD that averaged $-24 \mathrm{mEq} / 100 \mathrm{~g}$, targeting a urine $\mathrm{pH}$ of 5.5 to 6.0 , with total dietary $\mathrm{Ca}$ at $2.0 \% \mathrm{DM}$.

${ }^{4}$ The preplanned contrast statements were (1) CON versus the average of NDCA and ND and (2) NDCA versus ND.

${ }^{5}$ Samples were taken within $1 \mathrm{~h}$ of calving.

$0 \mathrm{mEq} / 100 \mathrm{~g}$ of $\mathrm{DM}$ with a urine $\mathrm{pH}$ of 7.32 ; and 3 ) an acidogenic diet, $-15 \mathrm{mEq} / 100 \mathrm{~g}$ of $\mathrm{DM}$ with a urine $\mathrm{pH}$ of 6.01. Dietary Ca was formulated for $1.5 \%$ of DM. They reported iCa concentrations averaged during the periparturient period $(-7$ and $-2 \mathrm{~d}$ prepartum and 0 $\mathrm{h}, 12 \mathrm{~h}$, and $1 \mathrm{~d}$ postpartum). Compared with a zero prepartum DCAD, the cows fed the acidogenic diet had greater iCa both prepartum and peripartum. The average of the periparturient samples also were above the $1.0 \mathrm{~m} M$ threshold that they used to determine $\mathrm{SCH}$. Decreasing urine $\mathrm{pH}$ to 7.3 was insufficient to reduce parturient hypocalcemia (Moore et al., 2000). Amundson et al. (2018) used a similar acidogenic diet, -16 to $-20 \mathrm{mEq} / 100 \mathrm{~g}$ of DM with a urine $\mathrm{pH}$ of 5.4 to 5.8 , with different levels of dietary Ca fed to nonlactating, nonpregnant cows as a model for transition cows. A hypocalcemia challenge was simulated by injecting $5 \%$ EGTA until iCa reached $60 \%$ of the initial concentration. Increasing dietary $\mathrm{Ca}$ to $2.0 \%$, compared with $0.46 \%$ and $1.1 \%$ of DM, resulted in a slower rate of decline in $\mathrm{iCa}$ and a greater overall $\mathrm{iCa}$ concentration during the hypocalcemia challenge (Amundson et al., 2018).

\section{Postpartum Production}

The postpartum period was separated into 2 subperiods: the fresh period representing the first 5 wk of lactation and the high period including wk 6 to 10 of lactation (Table 6). Cows fed CON tended $(P=0.08)$ to consume less DM (2.57\% of BW) postpartum than cows fed ND or NDCA $(2.77 \pm 0.11 \%$ BW $)$. Milk yield and milk components were not significantly different among treatments in the fresh period. A treatment by time interaction was detected for FCM and ECM $(P=$ 0.03 ), with FCM illustrated in Figure 3. The numerically greater yield by $\mathrm{CON}$ during wk 1 was short-lived with cows fed the acidogenic diets, ND and NDCA, showing greater yields during wk 2 to 3 . Milk yield did not differ among treatments in the high period.

Cows fed CON tended to have a greater fat-to-protein ratio (FPR) compared with cows fed ND or NDCA $(P$ $=0.09$ ). A higher FPR for cows fed CON likely reflected greater mobilization of body lipids. Development of fatty liver is associated with an FPR $>1.4$ (Duffield et al., 1997; Sawall and Litherland, 2013). Cows fed ND or NDCA did not differ for FPR $(P=0.30)$, and the FPR for cows fed NDCA (1.34) was below the threshold for concern. The greater SCC seen in cows fed CON during the fresh period $(P=0.11)$ approached our definition of statistical tendency when compared with cows fed ND or NDCA. The connection of how an improved Ca status postpartum relates to improved SCC, possibly through an effect on the immune system at the time of calving, merits future exploration.

Beneficial production results have generally been associated with prepartum acidogenic strategies, both in studies directly comparing specific programs and when comparing treatments through meta-analysis of publications spanning decades (Leno et al., 2017; Santos 
et al., 2019). However, the mechanism behind the increased milk yield is yet unclear. The direct association between Ca status after calving and milk production is not consistent. Jawor et al. (2012) controlled for the confounding effects of related metabolic disorders and found that cows considered hypocalcemic had greater milk yield than cows with normocalcemia. Their findings cannot be compared directly with our results because those authors (Jawor et al., 2012) used a cut-off for $\mathrm{SCH}$ of $<1.8 \mathrm{~m} M \mathrm{tCa}$ at $24 \mathrm{~h}$ after calving instead of the $<2.125 \mathrm{mM}$ tCa at $48 \mathrm{~h}$ after calving used in our study.

To explore alternative SCH thresholds and time points, the definitions used by Jawor et al. (2012) would result in $36 \%$ of cows fed $\mathrm{CON}$ labeled as $\mathrm{SCH}$ compared with $15 \%$ of cows fed ND and $23 \%$ of cows fed NDCA. Comparatively, Martinez et al. (2012) used the definition of serum $\mathrm{tCa}<2.148 \mathrm{~m} M$ at any point within the first 3 DIM. In this view, $89 \%$ of cows fed $\mathrm{CON}$ would be considered as having $\mathrm{SCH}$, compared with $44 \%$ of cows fed ND or $73 \%$ of cows fed NDCA. Based on the threshold and sampling time, the interpretation of SCH can be heavily influenced.

Recent debate continues to surround the defined thresholds and time points used to determine $\mathrm{SCH}$. In an attempt to explain the relationship between the initial drain on circulating $\mathrm{Ca}$, Ca recovery over multiple time points was explored (McArt and Neves, 2019). Cows with transient SCH (serum tCa concentration $\leq 2.125 \mathrm{mM}$ at $24 \mathrm{~h}$, but $>2.125 \mathrm{mM}$ at $48 \mathrm{~h}$ ) had greater milk yield and fewer negative health events than cows with either persistent SCH or normocalcemia (serum tCa $\leq 2.125 \mathrm{mM}$ or $>2.125 \mathrm{~m} M$, respectively, at both 24 and $48 \mathrm{~h}$ after calving; McArt and Neves, 2019). Age introduces an additional variable to consider as older cows are more susceptible to $\mathrm{SCH}$, but

Table 6. Least squares means for the fresh and high periods for DMI (fresh period only), milk yield, milk components ${ }^{1}$ (fresh period only), and BW for cows fed close-up dietary treatments CON, ND, or NDCA starting at -28 d relative to expected calving

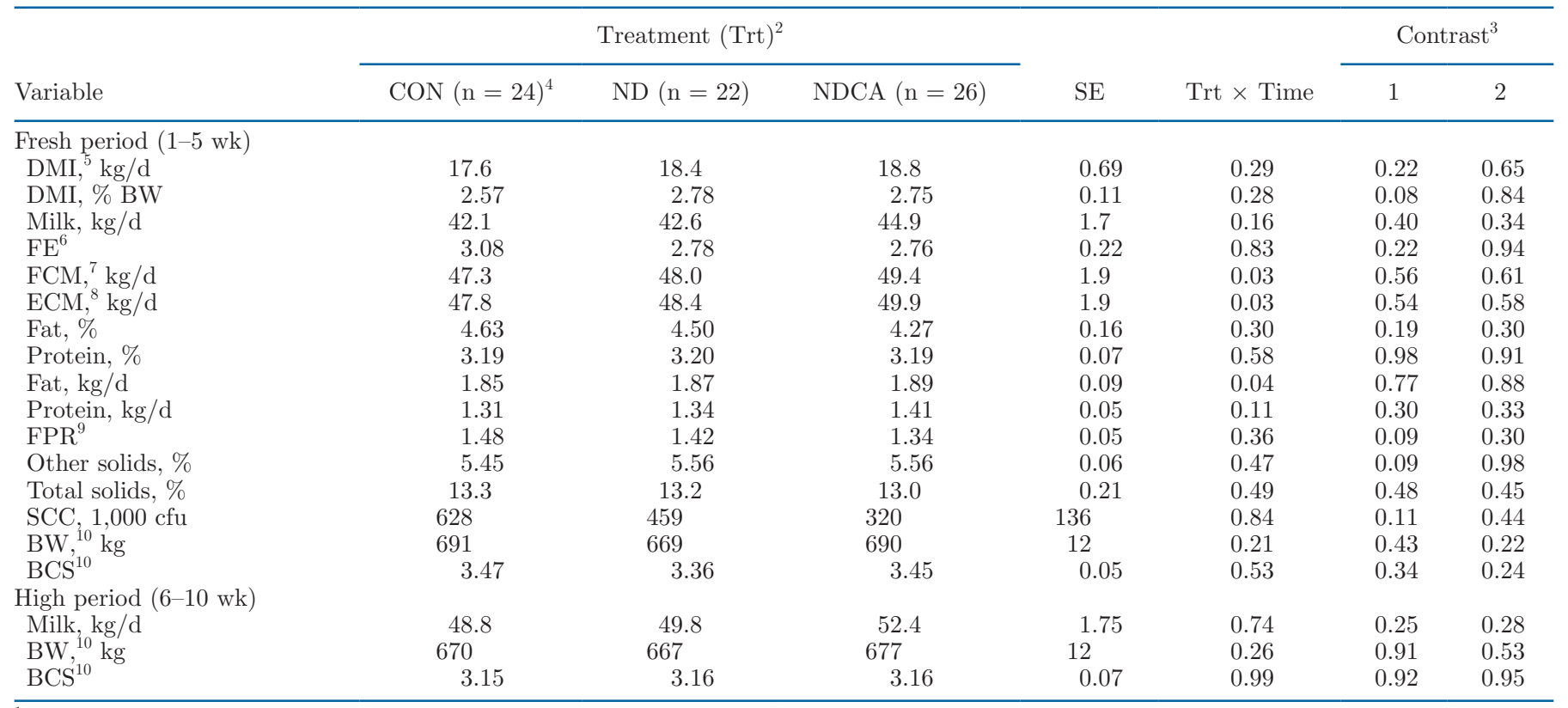

${ }^{1}$ Milk samples were obtained weekly during the fresh period from 3 consecutive milkings.

${ }^{2} \mathrm{CON}$ provided a positive DCAD that averaged $+6 \mathrm{mEq} / 100 \mathrm{~g}$, targeting a urine $\mathrm{pH}$ of $>7.5$, and total dietary $\mathrm{Ca}$ at $0.40 \% \mathrm{DM}$; $\mathrm{ND}$ (negative DCAD) provided a negative DCAD that averaged $-24 \mathrm{mEq} / 100 \mathrm{~g}$, targeting a urine $\mathrm{pH}$ of 5.5 to 6.0 , with total dietary Ca at $0.40 \% \mathrm{DM}$; and NDCA (negative DCAD plus added Ca) provided a negative DCAD that averaged $-24 \mathrm{mEq} / 100 \mathrm{~g}$, targeting a urine $\mathrm{pH}$ of 5.5 to 6.0 , with total dietary $\mathrm{Ca}$ at $2.0 \% \mathrm{DM}$.

${ }^{3}$ The preplanned contrast statements were (1) CON vs. the average of ND and NDCA and (2) ND vs. NDCA.

${ }^{4}$ Cows were excluded if diagnosed with clinical hypocalcemia or euthanized/died $(\mathrm{CON}=4, \mathrm{ND}=5, \mathrm{NDCA}=0)$.

${ }^{5}$ Dry matter intake was measured daily and summarized by week.

${ }^{6}$ Feed efficiency $(\mathrm{FE})=\mathrm{ECM}$ :DMI.

${ }^{7} \mathrm{FCM}=(0.515 \times$ milk weight $)+(13.86 \times$ fat weight $)($ Bethard, 2012).

${ }^{8}$ Energy-corrected milk calculated using the formula: $\mathrm{ECM}=(0.327 \times$ milk weight $)+(12.95 \times$ fat weight $)+(7.65 \times$ protein weight $)($ Orth, 1992).

${ }^{9}$ Fat:protein ratio.

${ }^{10} \mathrm{BW}$ and BCS were measured once weekly and were analyzed with a median adjustment. 
also have greater production potential (Caixeta et al., 2015). Greater milk yield may lead to an initial drain on the available Ca pool that must be recovered by 48 $\mathrm{h}$ to minimize the risk of negative health events. Future research could determine how older and higher producing cows may be able to use the greater Ca availability for other Ca-dependent functions, such as digestive system motility, rather than directly to milk yield.

Improvements in milk yield are generally accompanied by an increase in postpartum DMI. Our study reports greater numerical means for DMI and milk production during the fresh and high period for cows fed ND and NDCA compared with cows fed CON with the largest difference appearing between cows fed CON and cows fed NDCA. However, there was no statistical significance and our preplanned contrast statements do not allow for a direct comparison between $\mathrm{CON}$ and NDCA. Carryover effects of the differences in DMI prepartum may have diluted the effects of DMI postpartum. The lower energy high-straw diet fed as the base for all treatment groups during the prepartum period was designed to encourage DMI postpartum and ease the transition to the lactating diet (Dann et al., 2006; Janovick and Drackley, 2010). Further exploration into the prepartum DMI observed with the additional di- etary $\mathrm{Ca}$, outside of the direct comparison to an acidogenic diet with low dietary $\mathrm{Ca}$, is needed to explore the prepartum dietary $\mathrm{Ca}$ effect on postpartum production.

\section{Health}

Limited cow numbers and health events did not allow for significance to be determined among treatments for any individual disorder (Table 7). The USDA (2014) survey reported averages of $24.8,6.9,4.2$, and $4.5 \%$ for incidences of mastitis, metritis, ketosis, and retained placenta, respectively. Cows in our study experienced fewer than average cases of mastitis and metritis, but greater than average numbers of cases of ketosis and retained placenta compared with the USDA (2014) data. Cows fed CON had a greater adverse health score (2.39) compared with cows fed ND or NDCA $(1.23 \pm 0.05 ; P$ $=0.05)$. There was no difference in score between cows fed ND and NDCA. Our findings suggest that feeding an acidogenic prepartum diet can reduce the economic costs associated with health disorders compared with feeding a non-acidogenic diet prepartum.

Calcium is required for essential functions in support of the immune system and repair of the reproductive tract after calving (Kimura et al., 2002, 2006; Hammon

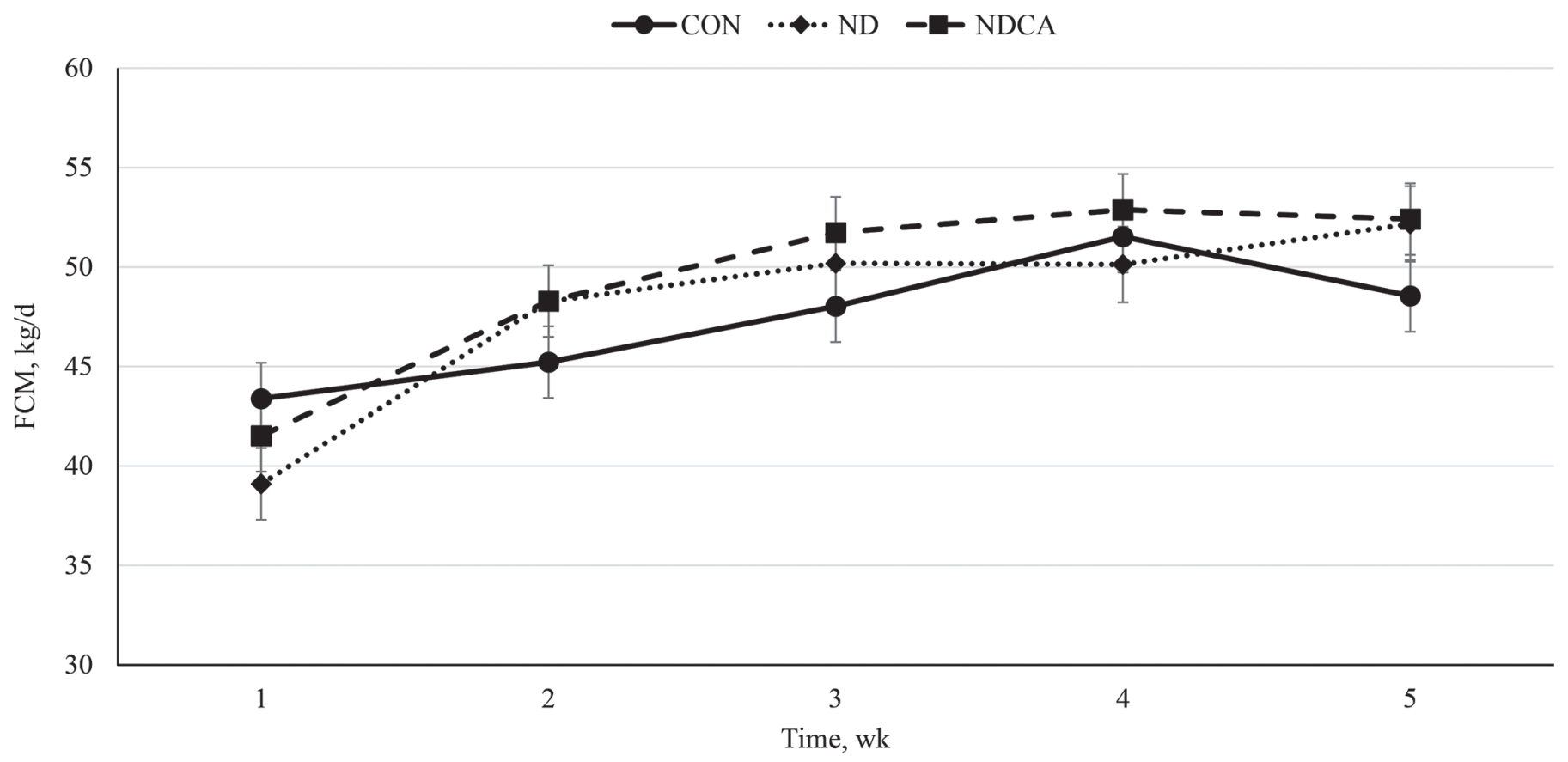

Figure 3. Least squares means of FCM, kg/d, summarized by week through the fresh period (first 5 wk postpartum) for cows fed prepartum dietary treatments: CON (control) provided a positive DCAD that averaged $+6 \mathrm{mEq} / 100 \mathrm{~g}$, targeting a urine $\mathrm{pH}$ of $>7.5$, and total dietary Ca at $0.40 \% \mathrm{DM}$; ND (negative DCAD) provided a negative DCAD that averaged $-24 \mathrm{mEq} / 100 \mathrm{~g}$, targeting a urine $\mathrm{pH}$ of 5.5 to 6.0 , with total dietary Ca at $0.40 \% \mathrm{DM}$; and NDCA (negative DCAD plus added Ca) provided a negative DCAD that averaged $-24 \mathrm{mEq} / 100 \mathrm{~g}$, targeting a urine $\mathrm{pH}$ of 5.5 to 6.0 , with total dietary Ca at 2.0\% DM. Animate supplementation (Phibro Animal Health Corp., Teaneck, NJ) was used to alter the prepartum DCAD and calcium carbonate was the source of additional Ca. Contrasts CON versus (ND and NDCA), $P<0.56$. Contrast ND versus NDCA, $P=0.61$. Treatment by time interaction, $P=0.03$. Error bars represent $\mathrm{SE}$. 
Table 7. Frequency of clinical health disorders from calving through 63 DIM, by treatment, for all cows fed close-up dietary treatments CON, $\mathrm{ND}$, or NDCA, starting at -28 d relative to expected calving

\begin{tabular}{|c|c|c|c|c|c|}
\hline \multirow[b]{2}{*}{ Variable $^{1}$} & \multicolumn{3}{|c|}{ Treatment $^{2}$} & \multicolumn{2}{|c|}{ Contrast $^{3}$} \\
\hline & $\mathrm{CON}(\mathrm{n}=28)$ & $\mathrm{ND}(\mathrm{n}=27)$ & NDCA $(\mathrm{n}=26)$ & 1 & 2 \\
\hline Retained placenta, n (\%) & $3(10.7)$ & $2(7.4)$ & $2(7.7)$ & 0.63 & 0.97 \\
\hline Displaced abomasum, n (\%) & $2(7.1)$ & $1(3.7)$ & $1(3.8)$ & 0.51 & 0.98 \\
\hline Milk fever, n (\%) & $2(7.1)$ & $3(11.1)$ & $0(0)$ & 0.98 & 0.98 \\
\hline Diarrhea, n (\%) & $1(3.6)$ & $0(0)$ & $1(3.8)$ & 0.98 & 0.98 \\
\hline Mastitis, n (\%) & $3(10.7)$ & $3(11.1)$ & $1(3.8)$ & 0.54 & 0.34 \\
\hline Metritis, $\mathrm{n} \%$ & $1(3.6)$ & $0(0)$ & $1(3.8)$ & 0.98 & 0.98 \\
\hline Euthanized or died, n \% & $5(17.9)$ & $2(7.4)$ & $1(3.8)$ & 0.10 & 0.58 \\
\hline Adverse health score ${ }^{4}$ & 2.39 & 1.51 & 0.94 & 0.05 & 0.42 \\
\hline
\end{tabular}

${ }^{1}$ Disorders were recorded if it was clinical and required medical intervention.

${ }^{2} \mathrm{CON}$ provided a positive DCAD that averaged $+6 \mathrm{mEq} / 100 \mathrm{~g}$, targeting a urine $\mathrm{pH}$ of $>7.5$, and total dietary Ca at $0.40 \% \mathrm{DM} ; \mathrm{ND}$ (negative DCAD) provided a negative DCAD that averaged $-24 \mathrm{mEq} / 100 \mathrm{~g}$, targeting a urine $\mathrm{pH}$ of 5.5 to 6.0 , with total dietary Ca at $0.40 \%$ DM; and NDCA (negative DCAD plus added Ca) provided a negative DCAD that averaged $-24 \mathrm{mEq} / 100 \mathrm{~g}$, targeting a urine $\mathrm{pH}$ of 5.5 to 6.0 , with total dietary $\mathrm{Ca}$ at $2.0 \% \mathrm{DM}$.

${ }^{3}$ The preplanned contrast statements were (1) CON vs. the average of NDCA and ND and (2) NDCA vs. ND.

${ }^{4}$ Calculated with events per cow, assigned a numerical value, and summed: no event $=0$, ketosis $=2$, retained placenta $=2$, displaced abomasum $=3$, milk fever $=2$, diarrhea $=2$, udder edema $=1$, fever $=1$, mastitis $=3$, metritis $=2$, euthanized $=5$.

et al., 2006). Ducusin et al. (2003) demonstrated that in vitro phagocytosis activity in polymorphonuclear leukocytes from hypocalcemic cows was impaired but adding $\mathrm{Ca}$ to the growth medium successfully restored functionality. Ryan et al. (2019) described the reproductive evaluation of the current study and reported improvements in reproductive health in cows fed an acidogenic diet compared with a non-acidogenic diet and in cows fed NDCA compared with ND. The improvements in reproductive function and health were reported as a decrease in days to first ovulation and services per conception, improvements in glandular morphology of uterine tissue, and an increase in neutrophil infiltration and the tight-junction protein occludin (Ryan et al., 2019). Combined with the improvements in the adverse health score and decreased SCC for cows fed acidogenic diets, these findings may indicate that Ca was directed toward immune health rather than milk production. Further investigation is needed to discover how $\mathrm{Ca}$ at the time of calving is prioritized in periparturient dairy cows.

\section{CONCLUSIONS}

Feeding an acidogenic diet, targeting urine $\mathrm{pH}$ of 5.5 to 6.0 in prepartum dairy cows, improved iCa at 24 $\mathrm{h}$ and tCa at $48 \mathrm{~h}$ compared with feeding a positive DCAD, low Ca diet. Although no significant production differences were detected, improvements in health were noted through a reduction in SCC and a lower calculated adverse health score in cows fed an acidogenic prepartum diet. Our results support previous findings that feeding an acidogenic prepartum diet improved postpartum Ca status and health. The addition of supplemental dietary $\mathrm{Ca}$ appeared to lessen the limiting effects of the acidogenic diet on DMI during the closeup period, but this should be confirmed in additional research. Additional $\mathrm{Ca}$ added to the acidogenic diet did not affect colostrum or milk production.

\section{ACKNOWLEDGMENTS}

We acknowledge Phibro Animal Health (Teaneck, NJ) for their financial support and providing the treatment feed additive Animate. We thank the staff, faculty, graduate students, and undergraduate employees at the University of Illinois, Department of Animal Sciences (Urbana, IL) for their help and support in completing this study. We also gratefully acknowledge donations of ProVAAl AAdvantage (Perdue AgriBusiness Animal Nutrition, Salisbury, MD), Smartamine M (Adisseo USA, Inc., Alpharetta, GA), and AjiPro-L (Ajinomoto Animal Nutrition North America Inc., Chicago, IL) used in this study. The authors have not stated any conflicts of interest.

\section{REFERENCES}

Amundson, L. A., A. D. Rowson, P. M. Crump, A. P. Prichard, A. A. Cheng, C. E. Wimmler, M. Klister, S. R. Weaver, S. S. Bascom, D. E. Nuzback, K. P. Zanzalari, and L. L. Hernandez. 2018. Effect of induced hypocalcemia in nonlactating, nonpregnant Holstein cows fed negative DCAD with low, medium, or high concentrations of 
calcium. J. Anim. Sci. 96:5010-5023. https://doi.org/10.1093/jas/ sky371.

Bethard, G. 2012. Impact of feeding efficiency on the income statement. Summit Proceedings. DAIReXNET, Kewaunee, WI.

Bréchard, S., and E. J. Tschirhart. 2008. Regulation of superoxide production in neutrophils: role of calcium influx. J. Leukoc. Biol. 84:1223-1237. https://doi.org/10.1189/jlb.0807553.

Caixeta, L. S., P. A. Ospina, M. B. Capel, and D. V. Nydam. 2015. The association of subclinical hypocalcemia, negative energy balance and disease with bodyweight change during the first 30 days post-partum in dairy cows milked with automatic milking systems. Vet. J. 204:150-156. https://doi.org/10.1016/j.tvj1.2015.01.021.

Chamberlin, W. G., J. R. Middleton, J. N. Spain, G. C. Johnson, M. R. Ellersieck, and P. Pithua. 2013. Subclinical hypocalcemia, plasma biochemical parameters, lipid metabolism, postpartum disease, and fertility in postparturient dairy cows. J. Dairy Sci. 96:7001-7013. https://doi.org/10.3168/jds.2013-6901.

Chan, P. S., J. W. West, and J. K. Bernard. 2006. Effect of prepartum dietary calcium on intake and serum and urinary mineral concentrations of cows. J. Dairy Sci. 89:704-713. https://doi.org/10 .3168/jds.S0022-0302(06)72133-6.

Chapinal, N., M. E. Carson, S. J. LeBlanc, K. E. Leslie, S. Godden, M. Capel, J. E. P. Santos, M. W. Overton, and T. F. Duffield. 2012. The association of serum metabolites in the transition period with milk production and early-lactation reproductive performance. J. Dairy Sci. 95:1301-1309. https://doi.org/10.3168/jds.2011-4724.

Charbonneau, E., D. Pellerin, and G. R. Oetzel. 2006. Impact of lowering dietary cation-anion difference in nonlactating dairy cows: A meta-analysis. J. Dairy Sci. 89:537-548. https://doi.org/10.3168/ jds.S0022-0302(06)72116-6.

Constable, P. D., C.-C. Gelfert, M. Fürll, R. Staufenbiel, and H. Stämpfli. 2009. Application of strong ion difference theory to urine and the relationship between urine $\mathrm{pH}$ and net acid excretion in cattle. Am. J. Vet. Res. 70:915-925. https://doi.org/10.2460/ajvr .70 .7 .915 .

Crenshaw, T. D., L. A. Rortvedt, and Z. Hassen. 2011. Triennial growth symposium: A novel pathway for vitamin D-mediated phosphate homeostasis: Implications for skeleton growth and mineralization. J. Anim. Sci. 89:1957-1964. https://doi.org/10.2527/ jas.2010-3411.

Dann, H. M., N. B. Litherland, J. P. Underwood, M. Bionaz, A. D'Angelo, J. W. McFadden, and J. K. Drackley. 2006. Diets during far-off and close-up dry periods affect periparturient metabolism and lactation in multiparous cows. J. Dairy Sci. 89:3563-3577. https://doi.org/10.3168/jds.S0022-0302(06)72396-7.

Diehl, A. L., J. K. Bernard, S. Tao, T. N. Smith, T. Marins, D. J. Kirk, D. J. McLean, and J. D. Chapman. 2018. Short communication: Blood mineral and gas concentrations of calves born to cows fed prepartum diets differing in dietary cation-anion difference and calcium concentration. J. Dairy Sci. 101:9048-9051. https://doi .org/10.3168/jds.2018-14829.

Ducusin, R. J. T., Y. Uzuka, E. Satoh, M. Otani, M. Nishimura, S. Tanabe, and T. Sarashina. 2003. Effects of extracellular Ca2+ on phagocytosis and intracellular $\mathrm{Ca} 2+$ concentrations in polymorphonuclear leukocytes of postpartum dairy cows. Res. Vet. Sci. 75:27-32. https://doi.org/10.1016/S0034-5288(03)00038-9.

Duffield, T. F., D. F. Kelton, K. E. Leslie, K. D. Lissemore, and J. H. Lumsden. 1997. Use of test day milk fat and milk protein to detect subclinical ketosis in dairy cattle in Ontario. Can. Vet. J. 38:713-718.

Edmonson, A. J., I. J. Lean, L. D. Weaver, T. Farver, and G. Webster. 1989. A body condition scoring chart for Holstein dairy cows. J. Dairy Sci. 72:68-78. https://doi.org/10.3168/jds.S0022 -0302(89)79081-0.

Glosson, K. M. 2018. Investigating the effect of yeast and mineral dietary supplements during the periparturient period on the production, physical health, and innate immune system of dairy cows. PhD Diss. Department of Animal Sciences, University of Illinois, Urbana.

Goff, J. P., and R. L. Horst. 1997. Effects of the addition of potassium or sodium, but not calcium, to prepartum rations on milk fever in dairy cows. J. Dairy Sci. 80:176-186. https://doi.org/10.3168/jds .S0022-0302(97)75925-3.

Goff, J. P., and N. J. Koszewski. 2018. Comparison of $0.46 \%$ calcium diets with and without added anions with a $0.7 \%$ calcium anionic diet as a means to reduce periparturient hypocalcemia. J. Dairy Sci. 101:5033-5045. https://doi.org/10.3168/jds.2017-13832.

Goff, J. P., A. Liesegang, and R. L. Horst. 2014. Diet-induced pseudohypoparathyroidism: A hypocalcemia and milk fever risk factor. J. Dairy Sci. 97:1520-1528. https://doi.org/10.3168/jds.2013-7467.

Grünberg, W., S. S. Donkin, and P. D. Constable. 2011. Periparturient effects of feeding a low dietary cation-anion difference diet on acidbase, calcium, and phosphorous homeostasis and on intravenous glucose tolerance test in high-producing dairy cows. J. Dairy Sci 94:727-745. https://doi.org/10.3168/jds.2010-3230.

Hammon, D. S., I. M. Evjen, T. R. Dhiman, J. P. Goff, and J. L. Walters. 2006. Neutrophil function and energy status in Holstein cows with uterine health disorders. Vet. Immunol. Immunopathol. 113:21-29. https://doi.org/10.1016/j.vetimm.2006.03.022.

Horst, R. L., J. P. Goff, and T. Reinhardt. 2005. Adapting to the transition between gestation and lactation: Differences between rat, human and dairy cow. J. Mammary Gland Biol. Neoplasia 10:141-156. https://doi.org/10.1007/s10911-005-5397-x.

Janovick, N. A., and J. K. Drackley. 2010. Prepartum dietary management of energy intake affects postpartum intake and lactation performance by primiparous and multiparous Holstein cows. J. Dairy Sci. 93:3086-3102. https://doi.org/10.3168/jds.2009-2656.

Jawor, P. E., J. M. Huzzey, S. J. LeBlanc, and M. A. G. von Keyserlingk. 2012. Associations of subclinical hypocalcemia at calving with milk yield, and feeding, drinking, and standing behaviors around parturition in Holstein cows. J. Dairy Sci. 95:1240-1248. https://doi.org/10.3168/jds.2011-4586.

Joyce, P. W., W. K. Sanchez, and J. P. Goff. 1997. Effect of anionic salts in prepartum diets based on alfalfa. J. Dairy Sci. 80:28662875. https://doi.org/10.3168/jds.S0022-0302(97)76251-9.

Kimura, K., J. P. Goff, M. E. Kehrli Jr., and T. A. Reinhardt. 2002. Decreased neutrophil function as a cause of retained placenta in dairy cattle. J. Dairy Sci. 85:544-550. https://doi.org/10.3168/jds .S0022-0302(02)74107-6.

Kimura, K., T. A. Reinhardt, and J. P. Goff. 2006. Parturition and hypocalcemia blunts calcium signals in immune cells of dairy cattle. J. Dairy Sci. 89:2588-2595. https://doi.org/10.3168/jds.S0022 $-0302(06) 72335-9$.

Lean, I. J., P. J. DeGaris, D. M. McNeil, and E. Block. 2006. Hypocalcemia in dairy cows: Meta-analysis and dietary cation anion difference theory revisited. J. Dairy Sci. 89:669-684. https://doi .org/10.3168/jds.S0022-0302(06)72130-0.

Lean, I. J., R. V. Saun, and P. J. DeGaris. 2013. Mineral and antioxidant management of transition dairy cows. Vet. Clin. North Am. Food Anim. Pract. 29:367-386. https://doi.org/10.1016/j.cvfa 2013.03.004.

Leno, B. M., C. M. Ryan, T. Stokol, D. Kirk, K. P. Zanzalari, J. D. Chapman, and T. R. Overton. 2017. Effects of prepartum dietary cation-anion difference on aspects of peripartum mineral and energy metabolism and performance of multiparous Holstein cows. J. Dairy Sci. 100:4604-4622. https://doi.org/10.3168/jds.2016-12221.

Liesegang, A., C. Chiappi, J. Risteli, J. Kessler, and H. D. Hess. 2007. Influence of different calcium contents in diets supplemented with anionic salts on bone metabolism in periparturient dairy cows. J. Anim. Physiol. Anim. Nutr. (Berl.) 91:120-129. https://doi.org/10 $.1111 /$ j.1439-0396.2006.00651.x.

Martinez, N., C. A. Risco, F. S. Lima, R. S. Bisinotto, L. F. Greco, E. S. Ribeiro, F. Maunsell, K. Galvão, and J. E. P. Santos. 2012. Evaluation of peripartal calcium status, energetic profile, and neutrophil function in dairy cows at low or high risk of developing uterine disease. J. Dairy Sci. 95:7158-7172. https://doi.org/10 $.3168 /$ jds.2012-5812.

Martinez, N., L. D. P. Sinedino, R. S. Bisinotto, R. Daetz, C. A. Risco, K. N. Galvão, W. W. Thatcher, and J. E. P. Santos. 2016. Effect of oral calcium supplementation on productive and reproductive performance in Holstein cows. J. Dairy Sci. 99:8417-8430. https:/ /doi.org/10.3168/jds.2015-10529. 
Martinez, N., L. D. P. Sinedino, R. S. Bisinotto, E. S. Ribeiro, G. C. Gomes, F. S. Lima, L. F. Greco, C. A. Risco, K. N. Galvão, D. Taylor-Rodriguez, J. P. Driver, W. W. Thatcher, and J. E. P. Santos. 2014. Effect of induced subclinical hypocalcemia on physiological responses and neutrophil function in dairy cows. J. Dairy Sci. 97:874-887. https://doi.org/10.3168/jds.2013-7408.

McArt, J. A. A., and R. C. Neves. 2019. Transient versus persistent subclinical hypocalcemia: Association of calcium status with early lactation disease and production in Holstein cows. J. Dairy Sci. 102(E-Suppl. 1):23. (Abstr.)

Megahed, A. A., M. W. H. Hiew, S. A. El Badawy, and P. D. Constable. 2018. Plasma calcium concentrations are decreased at least 9 hours before perturition in multiparous Holstein-Friesian cattle in a herd fed an acidogenic diet during late gestation. J. Dairy Sci. 101:1365-1378. https://doi.org/10.3168/jds.2017-13376.

Moore, S. J., M. J. VandeHaar, B. K. Sharma, T. E. Pilbeam, D. K. Beede, H. F. Bucholtz, J. S. Liesman, R. L. Horst, and J. P. Goff. 2000. Effects of altering dietary cation-anion difference on calcium and energy metabolism in peripartum cows. J. Dairy Sci. 83:20952104. https://doi.org/10.3168/jds.S0022-0302(00)75091-0.

Mulligan, F. J., and M. L. Doherty. 2008. Production diseases of the transition cow. Vet. J. 176:3-9. https://doi.org/10.1016/j.tvjl.2007 .12 .018 .

Mulligan, F. J., L. O'Grady, D. A. Rice, and M. L. Doherty. 2006. A herd health approach to dairy cow nutrition and production diseases of the transition cow. Anim. Reprod. Sci. 96:331-353. https: //doi.org/10.1016/j.anireprosci.2006.08.011.

Nace, E. L., S. C. Nickerson, F. M. Kautz, S. Breidling, D. Wochele, L. O. Ely, and D. J. Hurley. 2014. Modulation of innate immune function and phenotype in bred dairy heifers during the periparturient period induced by feeding an immunostimulant for 60 days prior to delivery. Vet. Immunol. Immunopathol. 161:240-250. https:// doi.org/10.1016/j.vetimm.2014.08.013.

Neves, R. C., B. M. Leno, M. D. Curler, M. J. Thomas, T. R. Overton, and J. A. A. McArt. 2018. Association of immediate postpartum plasma calcium concentration with early-lactation clinical diseases, culling, reproduction, and milk production in Holstein cows. J. Dairy Sci. 101:547-555. https://doi.org/10.3168/jds.2017-13313.

Oetzel, G. R. 1991. Meta-analysis of nutritional risk factors for milk fever in dairy cattle. J. Dairy Sci. 74:3900-3912. https://doi.org/ 10.3168/jds.S0022-0302(91)78583-4.

Orth, R. 1992. Sample day and lactation report. DHIA 200 Fact Sheet A-2. Mid-States Dairy Records Processing Center, Ames, IA.

Overton, T. R., and M. R. Waldron. 2004. Nutritional management of transition dairy cows: strategies to optimize metabolic health. J. Dairy Sci. 87(E Suppl.):E105-E119. https://doi.org/10.3168/jds .S0022-0302(04)70066-1.

Ramos-Nieves, J. M., B. J. Thering, M. R. Waldron, P. W. Jardon, and T. R. Overton. 2009. Effects of anion supplementation to low- potassium prepartum diets on macromineral status and performance of periparturient dairy cows. J. Dairy Sci. 92:5677-5691. https://doi.org/10.3168/jds.2009-2378.

Rodriguez, E. M., A. Bach, M. Devant, and A. Aris. 2016. Is calcitonin an active hormone in the onset and prevention of hypocalcemia in dairy cattle? J. Dairy Sci. 99:3023-3030. https://doi.org/10.3168/ jds.2015-10229.

Russell, K. E., and A. J. Roussel. 2007. Evaluation of the ruminant serum chemistry profile. Vet. Clin. North Am. Food Anim. Pract. 23:403-426. https://doi.org/10.1016/j.cvfa.2007.07.003.

Ryan, K. T., A. R. Guadagnin, K. M. Glosson, S. S. Bascom, A. D. Rowson, A. J. Steelman, and F. C. Cardoso. 2019. Increased dietary calcium inclusion in fully acidified prepartum diets improved postpartum uterine health and fertility when fed to Holstein cows. Theriogenology 142:338-347. https://doi.org/10.1016/ j.theriogenology.2019.10.014.

Santos, J. E. P., I. J. Lean, H. Golder, and E. Block. 2019. Meta-analysis of the effects of prepartum dietary cation-anion difference on performance and health of dairy cows. J. Dairy Sci. 102:2134-2154. https://doi.org/10.3168/jds.2018-14628.

Sawall, Z., and N. B. Litherland. 2013. Benefits of using milk fat to true protein ratio to evaluate on farm transition dairy cow lipid metabolism and effect of transition cow success on milk production. J. Dairy Sci. 96(E-suppl. 1):715 (Abstr.)

USDA (United States Department of Agriculture). 2014. Dairy 2014 Part I: Dairy Cattle Management Practices in the United States. USDA-Animal Plant Health Inspection-Veterinary Services-Center for Epidemiology and Animal Health--National Animal Health Monitoring System, ed, Fort Collins, CO. Accessed on April 21, 2020. https://www.aphis.usda.gov/animal_health/nahms/dairy/ downloads/dairy14/Dairy14_dr_PartI_1.pdf.

Weich, W., E. Block, and N. B. Litherland. 2013. Extended negative dietary cation-anion difference feeding does not negatively affect postpartum performance of multiparous dairy cows. J. Dairy Sci. 96:5780-5792. https://doi.org/10.3168/jds.2012-6479.

Zimpel, R., M. B. Poindexter, A. Vieira-Neto, E. Block, C. R. Staples, W. W. Thatcher, and J. E. P. Santos. 2018. Effect of dietary cation-anion difference on acid-base status and dry matter intake in dry pregnant cows. J. Dairy Sci. 101:8461-8475. https://doi.org/ 10.3168/jds.2018-14748.

\section{ORCIDS}

K. M. Glosson (® https://orcid.org/0000-0002-3268-385X S. S. Bascom ๑ https://orcid.org/0000-0002-5934-3206

J. K. Drackley $\odot$ https://orcid.org/0000-0002-4560-5594 